Swedish Institute for Social Research (SOFI)

Stockholm University

WORKING PAPER 6/2013

\title{
INDEPENDENT SCHOOLS AND LONG-RUN \\ EDUCATIONAL OUTCOMES - \\ EVIDENCE FROM SWEDEN'S LARGE SCALE \\ VOUCHER REFORM
}

by

Anders Böhlmark and Mikael Lindahl 


\title{
Independent Schools and Long-Run Educational Outcomes Evidence from Sweden's Large Scale Voucher Reform*
}

by

Anders Böhlmark and Mikael Lindahl

2013-10-22

\begin{abstract}
This paper evaluates the average educational performance effects of an expanding independentschool sector at the compulsory level by assessing a radical voucher reform that was implemented in Sweden in 1992. Beginning from a situation where all public schools were essentially local monopolists, the incidence of independent schools has developed very differently across municipalities over time as a result of this reform. We regress the change in educational performance outcomes on the increase in the share of independent-school students between Swedish municipalities. We find that an increase in the share of independent-school students improves average performance at the end of compulsory school as well as long-run educational outcomes. We challenge these results in several ways and find that they are highly robust to various endogeneity concerns such as pre-reform trends and other potential issues such as grade inflation. However, for most outcomes, we do not detect positive and statistically significant effects until approximately a decade after the reform. This finding is notable but not surprising, given that the first cohort of students who spent the entirety of their compulsory schooling in the new system graduated in 2001 and that it required time for independent schools to become more than a marginal phenomenon in Sweden. We further find that the average effects stem primarily from external effects (e.g., school competition) and not from independent-school students' gaining significantly more than public-school students. We do not find positive effects on school expenditures. We also reconcile our results with the deterioration of Swedish students' results in international tests. Using TIMSS data for 1995, 2003 and 2007, we find that the test results of Swedish students in the $8^{\text {th }}$ grade deteriorated less in regions with a higher proportion of independent school students.
\end{abstract}

Keywords: school choice; independent schools; educational performance; external effects JEL-codes: I2, H4

\footnotetext{
"This is a substantially revised and updated version of the working paper "Does School Privatization Improve Educational Achievement? Evidence from Sweden's Voucher Reform," (IZA DP 3691). We are grateful to Anders Björklund, Peter Fredriksson, Erik Grönqvist, Eric Hanushek, Lena Hensvik, Caroline Hoxby, Markus Jäntti, Matthew Lindquist, Dan-Olof Rooth and Jonas Vlachos for valuable comments and suggestions. We thank Eskil Forsell and Arvid Olovsson for excellent research assistance. We would also like to thank participants at the CESifo/PEPG economics of education conference in Munich, the IFN workshop on privatization in Vaxholm, and at seminars in Gothenburg, Stockholm (SOFI) and Uppsala (IFAU). Financial support from the Swedish Council for Working Life and Social Research (FAS), Jan Wallander and Tom Hedelius' Foundation, Granholms stiftelse, SCHOLAR, SUNSTRAT, and the Swedish Research Council (Vetenskapsrådet) is gratefully acknowledged. Mikael Lindahl is a Royal Swedish Academy of Sciences Research Fellow supported by a grant from the Torsten and Ragnar Söderberg Foundation, and also acknowledges financial support from the Scientific Council of Sweden and the European Research Council [ERC starting grant 241161]. Contact: Anders Böhlmark, SOFI, Stockholm University, IFAU and CREAM. Mikael Lindahl, Department of Economics, Uppsala University, CESifo, IFAU, IZA and UCLS. E-mails: anders.bohlmark@ sofi.su.se, mikael.lindahl@nek.uu.se.
} 
The theoretical arguments for why vouchers and school choice are expected to have positive effects on overall educational performance are well known. The main argument is that schools' incentive to improve is enhanced when they must compete for students. Because the money follows the students, the schools are expected to raise their quality to attract students. By allowing for alternatives to the local public school monopoly, one may also expect a better matching of students to schools and a greater influx of new ideas on how to improve teaching. However, despite the theoretical arguments that school choice should have a positive impact, the empirical evidence is mixed.

One of the most interesting evaluation settings comes from the experience in Sweden, which implemented a radical nationwide voucher reform in the early 1990s. The design of this reform essentially mimics the original idea proposed by Milton Friedman in his classic article “The role of government in education" from 1955: this reform introduced vouchers and free choice between public and independently run schools, similar economic terms for both types of schools, and fairly few regulations restricting new schools from entering the market. Before this reform, the public schools were local monopolists, and the few private schools that existed were not funded through vouchers and thus did not compete with public schools for students. Due to this reform, a completely new sector of publicly funded but independently run schools, which we call "independent schools," was created. ${ }^{1}$ Importantly, the full financing of the independent schools is provided by the local government in the form of a voucher for each student these schools attract. We thus expect stronger economic pressure on the local public schools as more students choose to opt out and attend independent schools.

Although the reform concerned the entire country, the establishment of independent schools has differed widely across municipalities; indeed, a sizeable fraction of the municipalities continue not to have any independent schools. Our basic evaluation strategy is to relate this differential growth in the share of independent-school students to changes in average educational outcomes across municipalities. We use high-quality administrative data for the entire Swedish population of students born 1972-1993 who finished compulsory school in Sweden between 1988 and 2009. We examine grades and test score outcomes at the

\footnotetext{
${ }^{1}$ We have decided to label these schools "independent schools" (in Swedish: "fristående skolor") because they are privately owned and operated but publicly funded. Earlier papers by us and others sometimes instead call them "private schools", which we believe is a less apt term, as it is associated with funding by student fees.
} 
end of compulsory school. ${ }^{2}$ We are also able to follow the students as they grow older and thus examine the effects on long-run outcomes such as high school grades, university attendance and years of schooling.

We find that an increase in the share of independent-school students has caused an increase in average educational performance. This increase is evident for both short- and long-run measures, and the estimates remain very similar if we control for changes in a number of demographic, family background and municipality-level characteristics. We also find that these positive effects are not driven by differential pre-reform trends in educational outcomes and that they are highly robust to a number of other issues that might bias the estimates (such as grade inflation and increased opportunities to choose between public schools). Our main estimations examine effects on educational performance using averages over both public and independent school students. Interestingly, it appears that the positive effects are primarily due to external effects (e.g., spillover or competition effects) and not that independent-school students gain significantly more than public school students. We are also able to show that a higher share of independent-school students in the municipality is not associated with an increase in school expenditures. However, for most measures, we do not detect positive and statistically significant educational performance effects until approximately a decade after the reform. This time lapse is notable but not surprising, as the first cohort of students who spent their entire compulsory schooling in the new system graduated in 2001 and because it has taken time for independent schools to become more than a marginal phenomenon in Sweden.

We also perform a separate analysis in which we are able to reconcile our results with the deterioration of Swedish students' results in international tests. Using TIMSS data for 1995, 2003 and 2007, we find that the test results of Swedish students in the $8^{\text {th }}$ grade deteriorated less in regions with a higher proportion of independent school students.

The paper is organized as follows. The next section provides a brief survey of the previous literature as well as a discussion of our contributions in relation to existing studies. Section 3 describes the Swedish school system, the voucher reform and the evolution of independent schools. Section 4 describes the data set and the variables used in the estimations. Section 5 discusses the estimation strategy and reports the main results for educational performance. Section 6 reports the results from a number of sensitivity analyses as well as from the

\footnotetext{
2 In Sweden, compulsory school denotes grade levels 1-9, which consist of stage 1 (grade levels 1-3), stage 2 (4-6) and stage 3 (7-9) education. Stages 1 and 2 are sometimes labeled as primary school, and stage 3 is sometimes labeled as lower secondary school.
} 
investigation of underlying mechanisms. Section 7 reports the results from TIMSS data. Section 8 concludes the paper.

\section{Previous studies and the value added of the present study}

There is an extensive literature that studies whether private (or other independent type) schools are better than public schools, and a number of papers have turned to quasiexperiments (e.g., voucher lotteries) in order to estimate the effects of attending these schools. ${ }^{3}$ However, students' choices are likely to have external effects. School choice might improve the quality of education for both private and public school students and lead to improved overall educational outcomes even if the students in private schools benefit no more than the students in public schools. Moreover, a reallocation of students among schools can generate peer-effects that can have both positive and negative effects. Only the private-school attendance effect can be estimated using small-scale voucher lotteries. To estimate the overall effect, researchers typically instead need to utilize large-scale school-choice reforms or peculiar institutional features of schooling systems to find credible exogenous variation in the degree of choice and competition across regions.

There is one strand of literature that evaluates choice between public schools or school districts and another that focuses on choice between different types of schools. We focus here on the latter literature. ${ }^{4}$ Hsieh and Urquiola (2006) estimate private school-choice effects from a large-scale reform that dramatically increased school choice in Chile during the 1980s. They found no impact on overall educational performance. Clark (2009) evaluates a U.K. reform where high schools were allowed to become autonomous (but still publicly funded) schools, the so called Grant-Maintained (GM) schools. Whether a local public school became a GM school depended on whether a majority of parents voted for the change. This rule in combination with vote shares is used in a Regression-Discontinuity estimation framework to evaluate the effects of GM schools. Clark finds large positive effects for these schools, but little spillover effects on the neighborhood schools. Card, Dooley and Payne (2010) evaluate whether competition between the publicly funded secular and Catholic primary schools

\footnotetext{
${ }^{3}$ Some recent examples of such work are: Angrist et al. (2006); Hoxby and Murarka (2009); and Abdulkadiroglu et al., (2011). For overviews of the literature, see McEwan (2000), Gill et al. (2007) and Bettinger (2011).

${ }^{4}$ Findings from some selected studies which have estimated achievement effects of choice and competition among public schools are: Positive effects are found for the U.S. (Hoxby, 2000) and for Israel (Lavy, 2008), whereas Gibbons, Machin and Silva (2008) find no effect for the U.K. de Haan, Leuven and Oosterbeek (2011) investigate competition effects in the Netherlands, where a universal voucher system exists. They find that fewer schools in an area lead to higher pupil achievement, which they argue is because the effect of school size offsets competition effects.
} 
(where the former is open to all students and the latter only to students with Catholic backgrounds) lead to more efficient schools. The argument is that the more Catholic families there are in an area, the more competitive pressure is put on the secular schools. The authors find small positive effects from increased competition on test score gains. There are also several studies of the effects of private school competition on the test scores of public school students in the U.S. Hoxby (2003) and Chakrabarti (2008) study the degree of vouchers offered to low-income students in the Milwaukee public schools and compare, in a differencein-differences setting, their test scores with those in similar Wisconsin schools. They find positive effects on public school test scores. Figlio and Hart (2010) study the effects of private school competition on the test scores of public school students in Florida. Utilizing a scholarship program offered to low-income students to attend private schools and variation across regions in access to private schools, they find that greater degrees of competition are associated with greater improvements in students' test scores following the introduction of the program. Since the estimates in these U.S. studies are for low-income students, their generalizability to other groups is likely limited. ${ }^{5}$

Our empirical approach, to relate the differential growth in the share of independentschool students to changes in average educational outcomes across municipalities, is similar to the approach used in Hsieh and Urquiola (2006) who utilize Chile's voucher reform and find no effect on educational outcomes. However, an advantage with our study is that we do have access to outcome variables for several school cohorts leaving compulsory school before the reform was implemented. We are therefore able to test for the existence of differential prereform trends in outcome variables across municipalities. If there was a higher demand for private voucher school slots in regions where the quality of public schools was deteriorating, the "no-effect" estimates in Hsieh and Urquiola (2006) would be expected to be downward biased. Although they acknowledge and discuss this extensively, they are not able to directly test for this because they lack outcome variables for the school cohorts finishing primary school prior to the reform.

There are a few previous studies that have looked at the effects of Sweden's independent schools on grades and test scores at the end of compulsory school (Ahlin, 2003, Björklund et al., 2005, and Sandström and Bergström, 2005). The findings range from statistically zero to very large effects. The first Swedish study was Sandström and Bergström (2005), which used individual-level data from 30 municipalities and studied the effects of the share of independent-school students on average grades and math test scores for public school

\footnotetext{
${ }^{5}$ See Gill (2007) for a discussion of this literature.
} 
students in 1998. Estimating OLS and IV models they find very large positive effects on math test scores. They also perform an analysis using aggregated data and examine the effects of the private school share on average grades for the years 1992 and 1994-1997. Using OLS they find significant positive effects, but for a specification with municipality fixed effects they find insignificant effects. Ahlin (2003) uses individual level data from 34 municipalities in 1998. Estimating value-added models she finds positive and significant effects of the share of independent-school students for tests scores in math but insignificant estimates for test scores in English and Swedish. Björklund et al. (2005) use data on test scores for individuals from 30 municipalities and on grades for the total population of pupils for the years 1998-2001. They estimate municipality FE models and find positive effects from the share of independentschool students for English and Swedish, and mixed results for math.

However, we believe that we can significantly extend and improve on the analysis in previous papers in several important ways. First, we look at new and better outcomes. Whereas previous papers have only looked at effects on grades and test scores at the end of compulsory school, we are able to track the individuals over time and, hence, also study medium and long-term effects (high school, university and years of schooling). In fact, studying effects on long-run outcomes is an advantage compared to almost all existing studies of overall effects of choice and competition. ${ }^{6} \mathrm{We}$ also use improved measures of achievement (covering almost $100 \%$ of the students) and of the share of independent schooling (built on the actual cohorts graduating from compulsory school). Second, we study a much longer time period, including 17 post-reform school cohorts as well as 5 pre-reform school cohorts. We use a large administrative data set of the whole Swedish population of individuals born 19721993 who finished compulsory school in Sweden between 1988 and 2009. Previous papers have only looked at earlier and fewer post-reform years. Because we aim to capture both short-term and long-term general equilibrium effects of independent schooling, we need to allow enough time before evaluation. It takes time for independent schools to be established, for public schools to respond and become more efficient and for students to be exposed to several years of education in competitive schools (independent or public). The data also allow us to investigate whether there are systematic differences in the trends in educational outcomes between municipalities prior to the implementation of the reform, an important issue which is not examined in the previous Swedish studies. ${ }^{7}$

\footnotetext{
${ }^{6}$ Hsieh and Urquiola (2006) look at effects on years of schooling, but for 10-15 year old children. They do not argue that this measure reflects long-term effects, but factors like age at entry, repetition, and dropout patterns.

${ }^{7}$ Hoxby (2003) writes that "one cannot test the hypothesis that competition among schools will raise productivity by looking at choice reforms that fail to introduce competitive incentives." Hence, "One must focus on reforms where: (a) at least a substantial share of a
} 


\section{Private schools, the voucher reform and the evolution of independent schools in Sweden}

Before 1992, pupils were assigned to, and required to attend, the public school in their local catchment area. The only alternative was to opt for one of the few private schools that existed. However, these accounted for less than one percent of total enrollment. ${ }^{8}$ Most of these schools were privately funded but some received state funding. Most importantly for this study, the funding of the public schools was independent of the number of pupils enrolled in the private schools. Hence, the few alternatives that existed did not exert any competitive pressure on the public schools. Moreover, these schools attracted a rather special selection of pupils: they were boarding schools (attracting a small selection of upper-class children); schools for pupils with special needs; international schools (mainly for foreign pupils); Christian-community schools; special pedagogy schools (e.g., Waldorf and Montessori).

Through a parliamentary decision, a voucher reform was introduced in 1992. A nonpublic school that decided to apply (and all existing private schools did, except for a few boarding schools) could receive approval (by the Swedish National Agency of Education) to become a voucher school. As a voucher school, the students' home municipalities had to provide the school with a grant, equivalent to (most of) the average per-student expenditure in the public school system for each student who choose to enroll in the school. ${ }^{9}$ This new law gave rise to a new type of non-public schools, "independent schools," whose existence entirely depends on funding through vouchers. The law also meant that the resources devoted to a public school in the student's home municipality became strongly affected by the choices of the students, since a student's choice of a independent school meant that the budget in the student's home municipality decreased by an amount equivalent to the voucher. ${ }^{10}$

As mentioned above, to be eligible for public funding through vouchers, non-public schools must be approved by the Swedish National Agency for Education (NAE) to become independent schools. These schools are allowed to deviate from the national curriculum, but

\footnotetext{
student's funding follows him from his regular public school to his choice school, (b) choice schools can expand and regular public schools can shrink, (c) choice schools do not depend (financially or for operating authority) on the regular public schools with which they are supposed to compete. In addition, it is practical to focus on reforms (d) that have been in place for several years, (e) in which the regular public schools could potentially lose more than a few percent of their students, and (f) for which ex ante data are available." We note that in our study, the setting and identification strategy is such that all these requirements are fulfilled.

${ }^{8}$ One has to go back to the 1920 s, before the creation of folkskolan, to find a sizeable fraction of students in private schools in Sweden at the compulsory level.

${ }^{9}$ The minimum required funding percentage has changed over the years. The school year 1992/1993, it was 85 percent, and in 1995 , 75 percent. It was less than 100 percent because of the extra costs involved for public schools regarding special education. In 1997, the system changed yet again: the size of the voucher should basically be equally large as the average cost per pupil in the respective municipality. Since 1992, however, the guiding principle has always been that public and independent schools should compete on equal terms.

${ }^{10}$ Note though that the municipality budget includes other social services as well (the school budget contains about $40 \%$ of the total municipality budget on average) which means that there is possible for municipalities to redistribute resources to schools with low demand, either by taking resources from other municipal public schools or from the budget for other social services.
} 
they must be open to all students. These schools are not allowed to select students by ability, socio-economic characteristics or ethnicity. If a school is oversubscribed, three selection criteria for admittance are allowed: proximity to the school; waiting list (where each child's place in line is determined by the date of the parents' application) and priority to children who have siblings already enrolled in the school. Independent schools are not allowed to charge any fees. ${ }^{11}$ Hence, top-up funding by student fees over and above the voucher is not allowed. Local authorities can appeal against the applications approved by the NAE, but the number of rejected applications has been small. ${ }^{12}$ Additionally, there are no restrictions on the ownership structure of the independent schools eligible for public funding - whether religious, non-profit cooperatives, or for-profit corporations. Hence, the regulation does not constitute a great obstacle for new schools to enter the market and receive public funding.

The first wave of independent schools after 1992 was primarily made up of special pedagogy schools and also some religious schools and parent cooperatives. Some of these existed as private schools prior to the reform but converted to voucher-funded independent schools after the reform. We may denote this initial wave of independent schools as being founded by idealists, and a non-profit organization was the typical owner at the time. After the early reform years, most new independent schools have been of a more general profile. These new type of independent schools, similar to the public schools in terms of their educational profile, have increasingly gained market share and are now the most common type. Contrary to the first wave, they compete by other means than offering something that is distinctly different from what is generally available in public schools. These schools were typically opened up by principals or teachers from the public school sector or by for-profit school corporations. School corporations started to establish themselves on the market in the late 1990s, and the number of schools run by such corporations has grown rapidly since then. Today, the typical owner of an independent school is a joint-stock company. The number of independent schools (with grade levels 7-9) has increased ten-fold since the reform, from 38 (3.8 percent of all schools) registered independent schools in 1993 to 396 (22.3 percent of all schools) in 2009.

\footnotetext{
${ }^{11}$ A small category of schools at the compulsory level is under a different regulation. These are 3 old boarding schools (Gränna, Lundsberg and Sigtuna) that exist outside of the voucher system and charge high fees. We exclude students in these schools in all our analysis done in this paper.

${ }^{12}$ For instance, in 2000, there were 153 applications to start an independent school at the compulsory level the following school year. Of these, 13 were rejected for reasons such as: the application was incomplete, the school was expected to not provide sufficient educational standard, or the owner was financially instable. Of these 13 applications, only 2 were denied because of an expectation that this independent school would lead to negative effects for the public schools in the municipality (Swedish National Agency for Education, 2001). From 2010, i.e., after our studied period, the number of rejections has increased significantly.
} 
Let us briefly compare the Swedish school choice system with that in some other countries. First, the full financing of independent schools comes from the local government (the municipality) ${ }^{13}$ in the form of a voucher for each student that they attract, which means that the amount of resources available for public schools in the municipality is negatively related to the number of students that choose to opt out and attend independent schools. Public schools will react to economic pressure if they care about revenues. For instance, since there are fixed costs involved in running a school, less resources will be available for teaching if revenues decrease. This also means that public teachers risk losing their job as the number of students decreases. Hence, there are clear economic incentives for local public schools to improve in Sweden. In this regard, Swedish independent schools share some similarities with Chilean private voucher schools and those U.S. charter schools that are funded by the local school districts. However, U.K. GM schools are different in that they are funded directly by the central government (as well as through donations from sponsors). Hence, although GM schools do compete for students with public schools, they probably exert less direct economic pressure on the neighborhood public schools (compared to what is the case with Swedish independent schools) as the central government could possibly redistribute money to keep poor public schools open. Second, independent schools are more autonomous than public schools (with respect to their budgets and their chosen curriculum) just as is the case for the Charter schools and the GM schools. ${ }^{14}$ A difference from the latter schools is that the ownership structure of independents schools can be very diverse (from for-profit companies to parent cooperatives). In this respect they are more similar to the Chilean private schools. Third, independent schools are not allowed to charge fees or to select students based on ability. Hence, we expect less impact on school segregation than what has been found from the establishment of the Chilean private-voucher schools. ${ }^{15}$

Figure 1 shows the evolution of the share of students in the independent schools at the end of compulsory school in Sweden between 1993 and 2009. ${ }^{16}$ The share of students in private non-voucher schools before the reform is represented by the dashed line. Only a small

\footnotetext{
${ }^{13}$ A Swedish municipality is similar to a school district in the U.S. or LEA in the U.K. in that it is the administrative economic unit as regards to the schools located in the area.

${ }^{14}$ Accountability of charter schools are also stronger than for independent schools, since once they have received a charter (which is a license to operate) they are contracted to follow their originally specified program and goals, and face a real risk of being closed down by a school board.

${ }^{15}$ There are some additional differences that are worth to notice when comparing the reforms in Sweden and Chile: First, whereas Chile had a sizeable sector of private schools before the reform (the private enrollment rate was about 20\%), the number of private schools in Sweden were negligible prior to the reform (the private enrollment rate was below 1\%). Second, most of the private schools in Chile were subsidized also prior to the reform, and the per-student subsidy rose from an average of $50 \%$ to $80 \%$ following the reform. In Sweden, pre-reform private schools were only eligible for subsidizes (from the central government) if they offered education that did not exist within the public sector. The pre-reform private sector in Sweden was essentially a small complement to the public school sector, and was never considered as an alternative to the great majority of students. As such, the potential competitive pressure on the public school sector was very limited.

${ }^{16}$ The share of independent-school students includes students from all voucher-receiving schools (including International schools and those special pedagogy schools for which we lack grades).
} 
fraction of students, below 1 percent, attended private schools before the reform in 1992, and this fraction was fairly constant until the reform. After the reform, not much happened during the first decade. However, beginning in the early 2000s there has been a sharp increase in the independent school share, and by 2009 it had increased to approximately 11 percent. We also note that previous Swedish studies used data for the school cohorts where only a few percent attended an independent school. The fraction of ninth-grade students attending an independent school was 1.6 percent in 1998 (the school cohorts used in Sandström and Bergström, 2005; Ahlin, 2003) and 1.6-3.1 percent in 1998-2001 (Björklund et al, 2005).

Figure 1: The share of private and independent school students 1988-2009

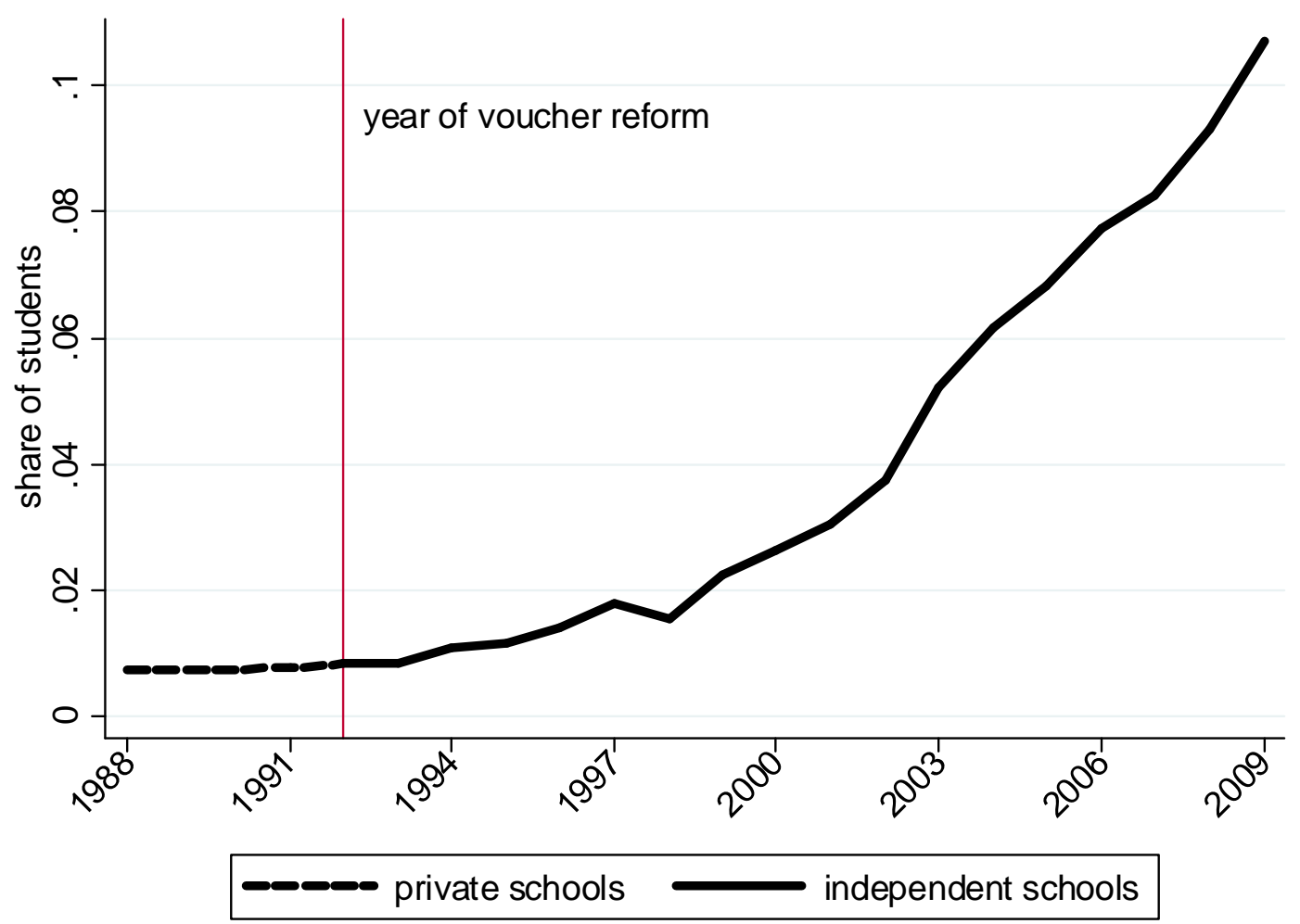

The establishment of independent schools has differed greatly across the 284 municipalities. In some municipalities it took much longer to open independent schools than in others, and in a large number of municipalities they still do not exist. Yet, other municipalities have faced substantial increases in independent-school enrollment. In the 128 municipalities where at least one independent school (with $9^{\text {th }}$ grade students) existed in 2009 , the average independent school share was 14 percent; the municipality with the largest share had 45 percent of its students in independent schools. 
In Figures $2 a$ and $2 b$, we present the distribution of the municipality-specific changes in the share of independent school students between 1992 and 2009. Figure 2a shows the distribution for schools in all municipalities, whereas figure $2 \mathrm{~b}$ only shows the distribution for the schools in the municipalities with at least one independent school in 2009. The vertical axis shows the proportion of municipalities in 2009 with a certain change. From figure $2 \mathrm{a}$, we see that the share has not changed at all in many municipalities. The unaffected municipalities constitute almost half of all municipalities but host less than 25 percent of the total student population. This is not surprising as the reform has had a small impact in more rural areas of Sweden. However, within the other half of the municipalities there are municipalities with both small and large changes over time (as illustrated in figure $2 b$ ).

Figure 2a: Histogram of the change in the share of independent school students 19922009 across municipalities

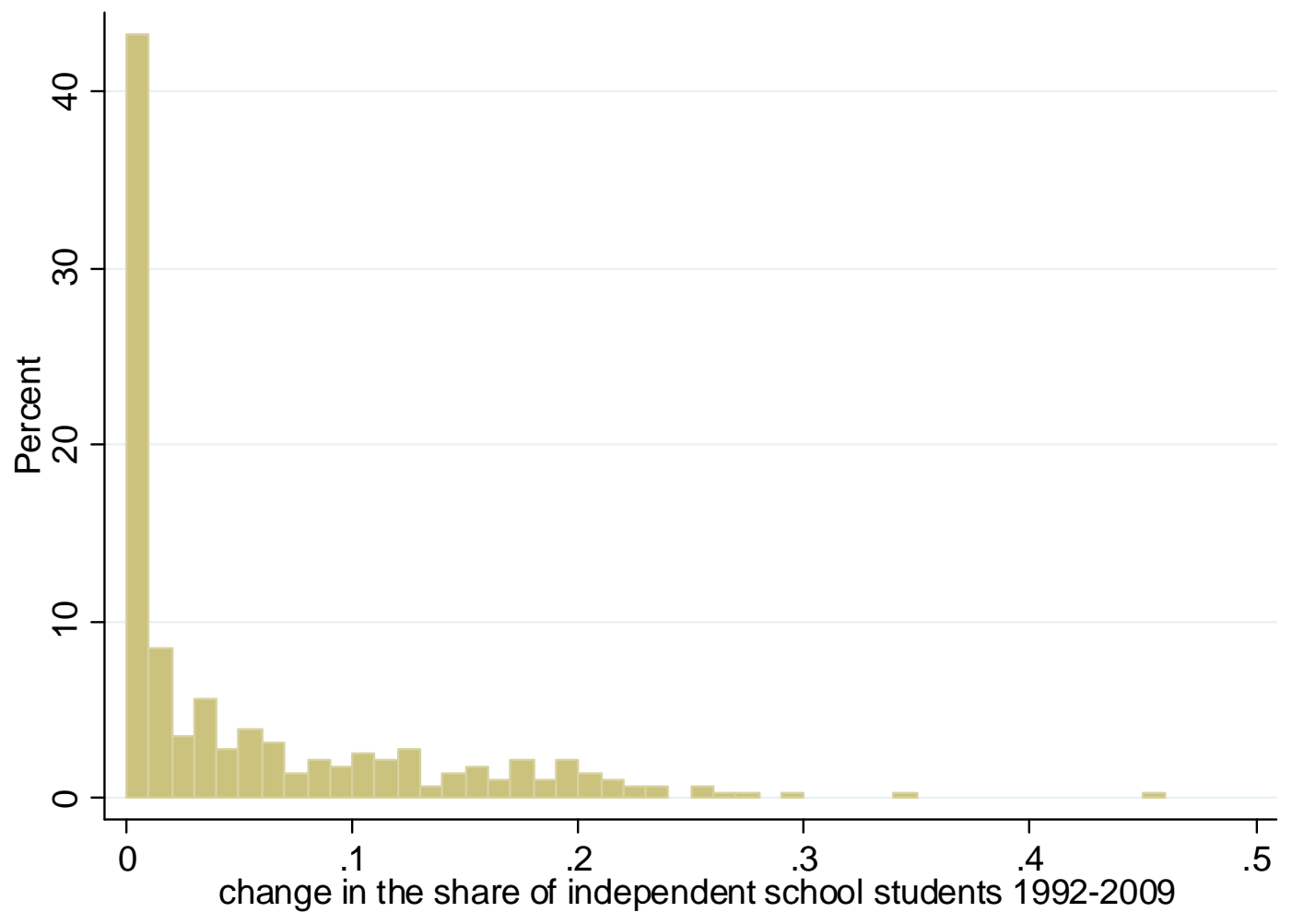


Figure 2b: Histogram of the change in the share of independent school students 1992-2009 across municipalities that had at least one independent school in 2009

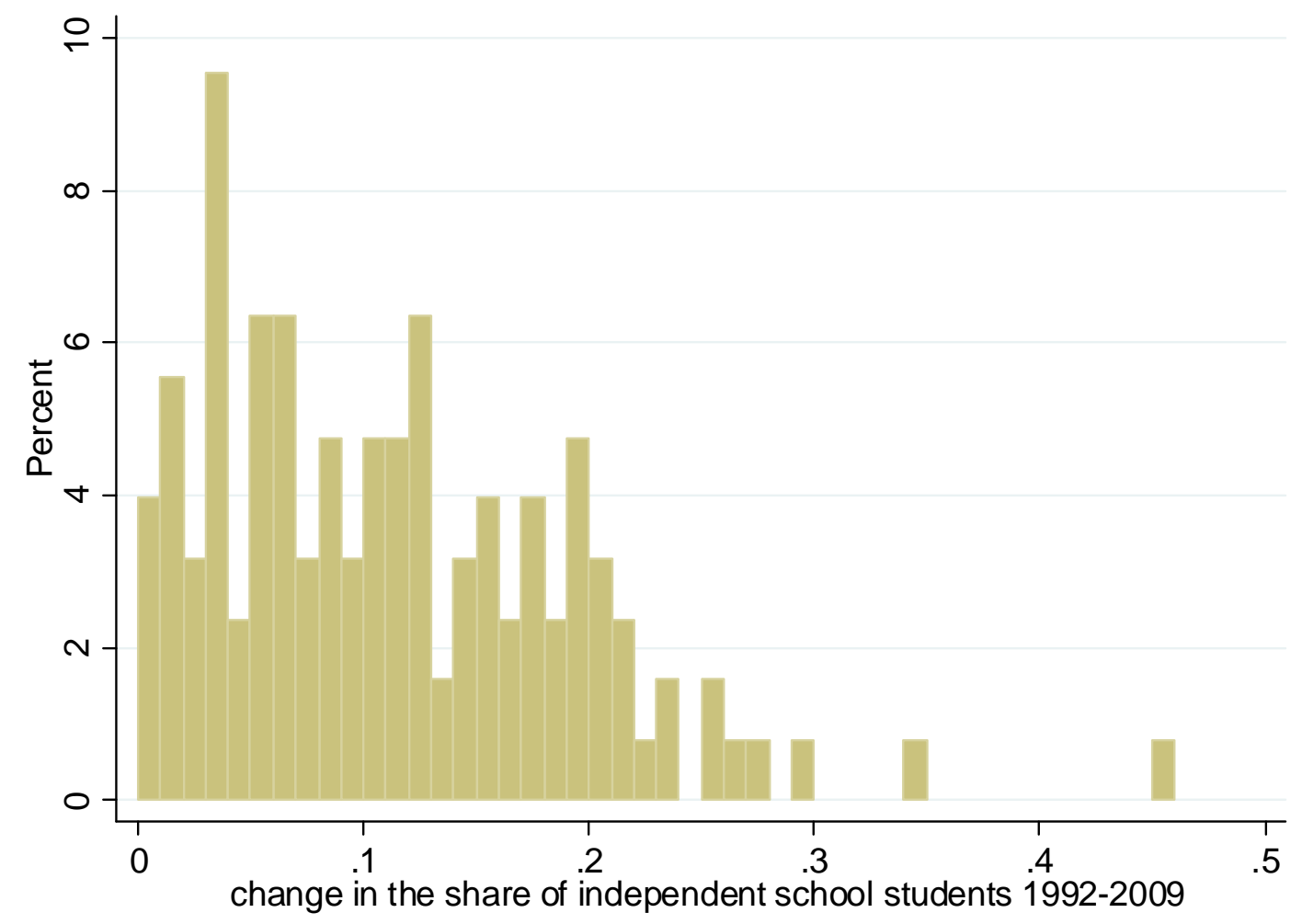

This differential increase in the share of independent-school students across municipalities constitutes a useful source of variation that we can exploit to net out the timeinvariant factors that are related to both the key independent variable and the outcome. Thus, if all of the determinants of independent-school enrollment are fixed municipal effects, we are able to identify the effects of interest just by using the panel dimension of the data to associate changes in the incidence of independent schooling to changes in educational achievement. However, there can also be relevant factors that change over time, and failing to control for these can lead to both positive and negative biases. For example, if the demand for independent-school slots is increasing in some municipalities due to a trend of highly educated parents moving in, this would likely lead to a positive bias. On the other hand, independent schools might tend to open up in areas where the public-school quality is trending downwards, something which would instead lead to a negative bias. The former (latter) issue would lead to an overestimate (underestimate) of the true impact of the share of independent school students on average student outcomes. Because of these issues we include controls for changes in municipality-average characteristics and examine the importance of 
pre-reform trends in the outcomes. We also estimate models where we only use the part of the variation in the growth in the share of independent school students that is determined by some features of the municipality that were in place already before the reform was implemented.

\section{Data and variable construction}

Our data set consists of all individuals finishing the $9^{\text {th }}$ grade of compulsory school (normally at age 16) each year from 1988-2009 in Sweden. The information on school grades and educational attainment is available for almost all pupils from the nationwide registers. Test scores from achievement tests conducted at the end of compulsory school are available for about $95 \%$ of the students for the years 2004-2009. We also have access to detailed demographic information on the students and data on the educational and economic outcomes of their parents. This data set provides information on the school attended and the region of residence for each student (at the time of $9^{\text {th }}$ grade attendance) as well as for the regional location of the school. ${ }^{17}$ The school registers contain information about all of the schools in Sweden, which allow us to identify whether a school is a public or an independent school. Henceforth, we use the term school cohort to denote the cohort of students who leave the $9^{\text {th }}$ grade in a certain year.

We analyze the following outcome variables, all aggregated over the students in a school cohort in a municipality: the average test scores in math and English at the end of compulsory school; the average grade scores in math and English at the end of compulsory school; ${ }^{18}$ the fraction of students choosing a science track in high school; the average grade scores in math and English after one year in High school (when courses in core subjects still are mandatory for all high school students); the fraction of students completing at least 1 semester of university education (at age 22, i.e., within 6 years of leaving compulsory school); and the average years of schooling (at age 24). To make the measures comparable, we standardize both test and grade scores to percentile rank scores. ${ }^{19}$

\footnotetext{
${ }^{17}$ Note that information about which school a pupil attended in grade 1-8 is not available from Swedish registers.

${ }^{18}$ Math and English were taught at two levels prior to 1998. To make grades in these subjects comparable across students we assume that the grade at the lower ( 1 to 5) level equals the grade at the higher (1 to 5) level minus one. This appears to be a reasonable approximation if one compares the math and English grades to grades in natural and social sciences, which were taught at only one level. Using alternative mappings do not alter the results. We do not utilize the grades in Swedish as a measure of school performance since separate classes and grading scales are given to natives and some in the immigrant population, and the fraction of immigrants taking special classes has changed a great deal over the years.

${ }^{19}$ We first convert the individual score to a percentile rank based on the distribution of scores in each subject for each school cohort in the whole country. We then use the average percentile rank of each pupil as the main measure of individual academic achievement. It is enough for a pupil to have grade in at least one of the core subjects to be included in the calculations. The reason to use percentile rank instead of raw scores is that we are forced to use grades from two different grading systems for the $9^{\text {th }}$ grade (from a relative to an absolute system starting with the 1998 school cohort), where transformation of scores across systems not is straightforward. By using percentile ranks conversion, we
} 
In our main estimations, we use changes in these outcome variables over time as dependent variables, where the changes are calculated from the last year before the reform was implemented (school cohort 1992) to the last post-reform year available in our data. Note that test score data are mostly unavailable for school cohorts prior to $2004 .^{20}$ We therefore instead calculate the change in average achievement as the difference between the average test scores in 2009 and the average grade scores in 1992. Although the grade and test score measures are not exactly comparable, we believe that it is much less of a problem to use grades prior to the reform compared to after the reform. The reason is that grades were then standardized based on results on national tests and that schools did then not face any competitive pressure and hence had little incentives to inflate grades with respect to test results. In fact, the grade system before 1998 was a relative system, meaning that the grades at the time were directly connected to results on the standardized national tests (in each main subject) and that school-level deviations were not allowed. Still, as a comparison and because high school track admittance is entirely based on grades, we also report results using the change in the average grade scores in English and math between 2009 and 1992 as the dependent variable. ${ }^{21}$

The key independent variable is the share of $9^{\text {th }}$-grade students living in a municipality who attend an independent school inside or outside the municipality's borders. Those students who choose to attend an independent school in another municipality bring their voucher from the municipality of residence. We calculate this measure for each year and municipality. All of the variables are aggregated up to the municipality-year level by school cohort and are hence based on individuals residing in a municipality at the time that they leave compulsory school no matter where they later live. Thus, we can really look at the overall impact of the share of independent-school students at the compulsory level for the very same individuals later in life. The key independent and dependent variables are all listed in Table 1 along with sample characteristics for the school cohorts 1992 and 2009 and for the change between these two years. As a comparison we also show sample characteristics for these variables at the student level in the table.

\footnotetext{
use the distribution of scores for each school cohort to combine the two. For high school grades, we only use data from the same system. We can therefore compare standardized estimates from using raw scores and percentile ranks. We find very similar effect sizes.

${ }^{20}$ Standardized national tests were given to students during the whole period, but before 2004 data on test scores were either only collected to national registers for a stratified sample of municipalities (and where the sampled municipalities typically differed for each year) or not at all.

${ }^{21}$ The possibility that subjective grade setting by teachers and that differential grading standards might have developed between municipalities with differential independent-school penetration are examined in section 5.1.
} 


\begin{tabular}{|c|c|c|c|c|c|c|c|c|c|c|}
\hline \multirow{3}{*}{$\begin{array}{l}\text { Table } 1 \text { Descriptive statistics } \\
\text { Graduation year }\end{array}$} & \multicolumn{4}{|c|}{ Student level } & \multicolumn{6}{|c|}{ Municipality level } \\
\hline & \multicolumn{2}{|c|}{1992} & \multicolumn{2}{|c|}{2009} & \multicolumn{2}{|c|}{1992} & \multicolumn{2}{|c|}{2009} & \multicolumn{2}{|c|}{ Diff: $2009-1992$} \\
\hline & Mean & St. dev. & Mean & St. dev. & Mean & St.dev. & Mean & St.dev. & Mean & St.dev. \\
\hline \multicolumn{11}{|l|}{ INDEPENDENT SCHOOL VARIABLES } \\
\hline$\overline{\text { Share of independent school students }}$ & 0 & 0 & .107 & .309 & 0 & 0 & .057 & .076 & .057 & .076 \\
\hline Share of independent schools & 0 & 0 & .223 & .17 & 0 & 0 & .133 & .173 & .133 & .173 \\
\hline Share of non-voucher private school students (pre-reform) & .008 & .02 & & & .0016 & .0092 & & & & \\
\hline \multicolumn{11}{|l|}{ EDUCATIONAL OUTCOMES } \\
\hline Mean of math \& English test score in $9^{\text {th }}$ grade & 49.9 & 25 & 49.5 & 22.6 & 48.9 & 3.65 & 47.3 & 4.73 & -1.6 & 4.06 \\
\hline Mean of math \& English grade at end of $9^{\text {th }}$ grade & 49.9 & 25 & 50.1 & 23.8 & 48.9 & 3.65 & 48.1 & 4.25 & -.738 & 3.82 \\
\hline Academic track in high school ${ }^{\mathrm{a}}$ & .53 & .50 & .50 & .50 & .48 & .10 & .44 & .11 & -.045 & .092 \\
\hline GPA in high school, A-courses, all tracks ${ }^{\mathrm{a}}$ & 49.7 & 20.8 & 50.0 & 21.6 & 48.7 & 3.57 & 48.0 & 3.91 & -.645 & 4.05 \\
\hline At least 1 semester of university studies at age $22^{\mathrm{b}}$ & .212 & .409 & .235 & .424 & .193 & .055 & .209 & .052 & .016 & .05 \\
\hline Years of schooling at age $24^{c}$ & 12.5 & 1.61 & 12.4 & 1.65 & 12.4 & .228 & 12.4 & .209 & -.045 & .21 \\
\hline \multicolumn{11}{|l|}{ FAMILY AND DEMOGRAPHIC VARS, POPULATION SIZE } \\
\hline$\overline{\text { At least one parent university educated }}$ & .314 & .464 & .397 & .489 & .272 & .085 & .341 & .093 & .069 & .059 \\
\hline At least one parent high school educated & .783 & .412 & .903 & .296 & .766 & .065 & .911 & .035 & .145 & .059 \\
\hline Log family earnings & 11.9 & .876 & 12.2 & .937 & 11.8 & .158 & 12.2 & .164 & .331 & .114 \\
\hline Log family earnings is missing (unempl.proxy) & .018 & .131 & .009 & .095 & .016 & .012 & .0085 & .0081 & -.0075 & .013 \\
\hline 2nd generation immigrant & .046 & .21 & .089 & .285 & .034 & .039 & .052 & .053 & .018 & .038 \\
\hline Immigrant & .063 & .243 & .067 & .251 & .048 & .032 & .052 & .027 & .0044 & .028 \\
\hline No of $9^{\text {th }}$ grade students in municipality & 920 & .0011 & 1500 & 2100 & 346 & 446 & 419 & 677 & 72.8 & 247 \\
\hline \multicolumn{11}{|l|}{$\begin{array}{l}\text { PUBLIC SCHOOL CHOICE, SCHOOL RESOURCES, POLITICAL } \\
\text { VARS. AND PRE-REFORM MARKET OPPORTUNITIES }\end{array}$} \\
\hline $\begin{array}{l}\text { Share of students who choose another public school than the one that } \\
\text { students in the same neighborhood typically attend }\end{array}$ & .126 & .075 & .251 & .122 & .089 & .075 & .161 & .118 & .072 & .09 \\
\hline Log school expenditures per pupil & 10.9 & .094 & 11.2 & .076 & 10.9 & .115 & 11.3 & .103 & .348 & .103 \\
\hline Right-wing majority & .252 & .434 & .253 & .435 & .331 & .471 & .342 & .475 & .011 & .38 \\
\hline Coalition & .35 & .477 & .434 & .496 & .229 & .421 & .282 & .451 & .053 & .532 \\
\hline Pre-reform student base in $1992^{\mathrm{d}}$ & & & & & -.0001 & .182 & & & & \\
\hline Private school in municipality in 1992 & & & & & .067 & .25 & & & & \\
\hline More than one public school in 1992 & & & & & .673 & .47 & & & & \\
\hline
\end{tabular}

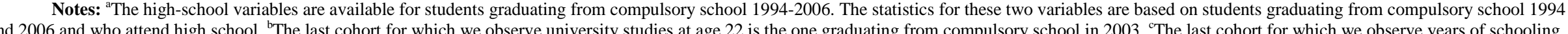
at age 24 is the one graduating from compulsory school in 2001. "The following control variables are not listed in the table (but belong to this set, and are included in all estimations where this set is included): Gender of student, Parent's average age at birth of child, Mothers years of schooling; Fathers years of schooling; indicator variables for missing parental schooling; immigrants' age at immigration. Earnings are coded missing if less than 20,000 SEK (about 2,500 USD in year 2000 prices). Family earnings are the average of the sum of the parents' earnings when the child is 5 and 10 years old. Earnings and school expenditures are expressed in

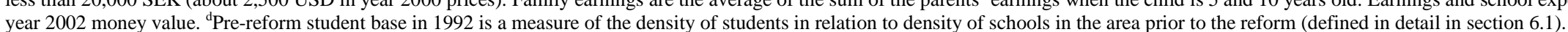


The statistics for the change between 1992 and 2009 are based on unweighted aggregated data for all municipalities, i.e., we treat each municipality as a "market" for school slots. These figures are hence based on the individual characteristics aggregated up to the municipality-year (school cohort) level. The first panel presents the independent-school variables. We see that the share of independent-school students was zero before the reform in 1992. The share of (non-voucher) private school students was 0.8 percent in 1992. Since these schools did not compete with the public schools in the school districts (and because we lack grades for these students), we ignore this fraction in our main estimations. ${ }^{22}$ Including them has no impact on our estimates (see results in section 6.1). We see that the average growth in the share of independent-school students is about 6 percent (keep in mind that the change is zero in more than half of the municipalities). This number is lower than the change in the share of independent schools because the independent schools are, on average, smaller than the public schools. The second and third panels present the statistics for the educational outcomes and the family background and demographic control variables. In the last part of Table 1, we show the statistics for some variables that we later use in our sensitivity analysis (section 6.1.). ${ }^{23}$

\section{The effect of the share of students attending independent schools on average educational performance}

\subsection{Empirical setup}

Our basic model expresses the relationship between average educational performance and the share of students attending independent schools as

$$
\bar{Y}_{m t}=\gamma_{\mathrm{m}}+\alpha_{\mathrm{t}}+\beta \bar{P}_{m t}+\lambda \bar{X}_{m t}+\varepsilon_{\mathrm{mt}}
$$

where $\gamma_{\mathrm{m}}$ represents unobservable municipality characteristics that are constant over time; $\alpha_{\mathrm{t}}$ represents unobservable school-cohort characteristics that are constant across municipalities; $\bar{X}_{m t}$ is a vector of municipality characteristics (average demographic and family background characteristics, as listed in Table 1, and the number of students); and $\bar{P}_{m t}$ is the share of

\footnotetext{
${ }^{22}$ Hence the share in 2009 is the same as the change in this share between 1992 and 2009 since no voucher-funded private schools existed before the reform.

${ }^{23}$ We thank Per Pettersson-Lidbom for providing us with data on political majorities in municipalities. The political majority variables are lagged 3 years.
} 
students attending independent schools in municipality $\mathrm{m}$ at time $\mathrm{t}$. Note that $\bar{P}_{m t}=0$ for the school cohorts graduating before the reform because the independent schools then did not exist.

To eliminate unobservable municipality specific characteristics, we take the difference of (1) expressed for a post reform and the last pre-reform cohort. This generates

$$
\Delta \bar{Y}_{m}=\mathrm{c}+\beta \Delta \bar{P}_{m}+\lambda \Delta \bar{X}_{m}+\Delta \varepsilon_{m}
$$

Focusing on the last post-reform cohort for which data are available, we have that $\Delta \bar{Y}_{m}$ denotes the change in the average educational outcome between the last pre-reform school cohort in 1992 and the last available post-reform school cohort $t$ ', which is 2009 for the compulsory school test and grade scores, 2006 for the academic track and high school grades, 2003 for university attendance and 2001 for years of schooling for students residing in municipality $m$ in those years. $\Delta \bar{P}_{m}$ denotes the change in the share of independent-school students residing in municipality $m$ between 1992 and the last available post-reform school cohort; $\Delta \bar{X}_{m}$ denotes the change in the vector of municipality characteristics in municipality $m$ between 1992 and the last available post reform school cohort and is included to correct for changes in the composition of students; and $\Delta \varepsilon_{m}$ is a random error term.

The key identifying assumption to arrive at a consistent estimate of $\beta$ using OLS on (2) is that, conditional on $\Delta \bar{X}_{m}, \operatorname{Cov}\left(\Delta \bar{P}_{m}, \Delta \varepsilon_{\mathrm{m}}\right)=0$ holds. Hence, changes in the unobservable factors (that impact $\Delta \bar{Y}_{m}$ ) between 0 and t' should not be correlated with the change in the share of students in independent schools between 0 and $t{ }^{2} .{ }^{24} \mathrm{We}$ investigate a number of threats to the identification below. Since the treatment (the share of independent school students) is defined at the municipality level and because we are interested in how the typical student in each municipality is affected (and not the average student in the country) we give each municipality equal weight in the estimations. As it turns out, weighting by the number of students in each municipality has little impact on the estimates.

There are two main reasons why we have chosen to eliminate $\gamma_{\mathrm{m}}$ by taking first differences over the entire period (instead of using all school cohorts and estimating equation (1) directly). First, we want to use the variation over the entire period because there has been a consistent growth in the share of independent school students over time (see figure 1). Second, because we aim to capture long-term general equilibrium effects of independent

\footnotetext{
${ }^{24}$ Note that since $\bar{P}_{m t}=0$ for pre-reform school cohorts, we get that $\Delta \bar{P}_{m}=\bar{P}_{m t}$, where t' is the last post-reform year. Hence, it is sufficient if $\operatorname{Cov}\left(\bar{P}_{m t^{\prime}}, \Delta \varepsilon_{\mathrm{m}}\right)=0$.
} 
schooling we believe there it is necessary to allow as much time as possible before evaluation. ${ }^{25} \mathrm{We}$ also note that $\beta$ in model (2) is the difference-in-differences estimator (where we have allowed for variable treatment intensity as in Duflo, 2001), comparing changes between municipalities over time from the last pre-reform year to the last post-reform year $t \cdot{ }^{26}$

One main worry is that the pre-reform trends vary in a way that can bias our estimates. For instance, if independent-schools were more likely to be established in municipalities with failing public schools, the estimation of model (2) will lead to a downward-biased estimate of $\beta$. Of course, one could think of alternative scenarios where differential pre-reform trends lead to overestimates of $\beta$. We therefore perform counterfactual estimations where we regress the change in our outcome variables before the reform was implemented on the growth of independent-schooling after the reform was implemented. If an association exists, we interpret it as evidence of pre-reform trends varying systematically across municipalities, which would produce biased estimates in our main regressions. We estimate:

$$
\Delta \bar{y}_{m, p r e}=\mathrm{c}^{\prime}+\beta^{\prime} \Delta \bar{P}_{m}+\lambda{ }^{\prime} \Delta \bar{X}_{m}+\Delta \varepsilon_{m, p r e},
$$

where $\Delta \bar{Y}_{m, p r e}$ denotes the change in the average educational outcome between 1988 and 1992 for the students residing in municipality $m$ during those years; $\Delta \bar{P}_{m}$ and $\Delta \bar{X}_{m}$ are the same variables as in equation (2); and $\Delta \varepsilon_{m, p r e}$ is a random error term.

\subsection{Main Results}

We start by associating the change in our educational performance variables with the growth in the share of independent-school students, i.e., we estimate equation (2). Table 2 reports the results from estimating two different versions of this model. We show estimates from models without any controls in column 1 and with controls in column 2.

\footnotetext{
${ }^{25}$ A potential drawback with estimating (2) instead of (1) is that we cannot control for post-reform municipality specific trends. However, we test for, and reject, the importance of pre-reform municipality specific trends below (i.e., we test if the key assumption in difference-indifferences models hold). We believe that it would be problematic to control for post-reform municipality trends as we then would compare, not changes in levels over time, but instead changes in slopes over time. It is unclear why this would be a more relevant source of variation. ${ }^{26}$ In an earlier version of this paper (Böhlmark and Lindahl, 2008) we did use all school cohorts and estimated equation (1) directly using individual level data (controlling for municipality fixed effects to take into account unobservable fixed municipality characteristics). This approach is more efficient given that the assumption of strict exogeneity for all $\mathrm{t}$ hold. However, as it uses year-to-year variation in the share of independent school students within municipalities, it is also more sensitive to measurement error.
} 
Table 2: OLS Regressions of changes in the share of independent-school students on post- and pre-reform changes in overall educational achievement

$\begin{array}{cc}\text { Main Estimations: } & \text { Counterfactual Estimations: } \\ \text { Post reform changes in outcomes } & \underline{\text { Pre-reform changes in outcomes }}\end{array}$

\begin{tabular}{lcccc}
\hline & $(1)$ & $(2)$ & $(3)$ & $(4)$ \\
\hline Educational performance outcomes & & & & \\
Test scores in English and math & 16.95 & 17.93 & $\mathrm{NA}$ & $\mathrm{NA}$ \\
& $(2.69)^{* *}$ & $(2.69)^{* *}$ & & \\
$\mathrm{R} 2$ & 0.10 & 0.28 & & -3.80 \\
Grades in English and math & 14.44 & 15.76 & -2.60 & $(2.38)$ \\
R2 & $(2.60)^{* *}$ & $(2.55)^{* *}$ & $(1.98)$ & 0.06 \\
& 0.08 & 0.28 & 0.00 & 0.10 \\
Academic track in high school & 0.25 & 0.19 & 0.11 & $(0.07)$ \\
R2 & $(0.12)^{*}$ & $(0.13)$ & $(0.06)+$ & 0.05 \\
Grades in 1 & 0.02 & 0.07 & 0.01 & $\mathrm{NA}$ \\
English and math in high school & 20.26 & 17.47 & $\mathrm{NA}$ & \\
R2 & $(3.40)^{* *}$ & $(3.83)^{* *}$ & & -0.02 \\
At least 1 semester of university & 0.08 & 0.17 & & $(0.07)$ \\
studies at age 22 & 0.16 & 0.19 & 0.03 & 0.13 \\
R2 & $(0.05)^{* *}$ & $(0.06)^{* *}$ & $(0.05)$ & 0.10 \\
Years of schooling at age 24 & 0.02 & 0.17 & 0.00 & $(0.37)$ \\
R2 & 0.73 & 0.64 & -0.21 & 0.09 \\
Controls & $(0.33)^{*}$ & $(0.35)+$ & $(0.34)$ & YES \\
Changes in municipal controls ${ }^{\mathrm{a}}$ & 0.01 & 0.17 & 0.00 & \\
& & & $\mathrm{NO}$ &
\end{tabular}

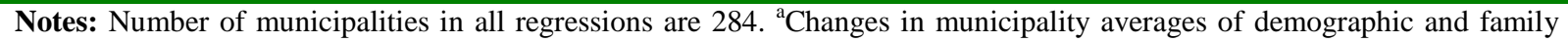
background variables: parents' earnings; parents' education; parents' age; immigrant status; parents' immigrant status; size of the student population (see Table 1 for details). Post-reform changes in test scores and in all other variables are calculated for 1992-2009 when test scores and grades are the dependent variables. Post-reform changes in the high-school variables and in all other variables are calculated for 1994-2006 when the high-school variables are the outcomes. Post-reform changes in "At least 1 semester of university studies at age 22" and in all other variables are calculated for 1992-2003 when "At least 1 semester of university studies at age 22" is the outcome. Post-reform changes in "Years of schooling at age 24" and in all other variables are calculated for 1992-2001 when "Years of schooling at age 24" is the outcome. Pre-reform changes in the dependent variables are calculated for 1988-1992. Robust standard errors are in parentheses. + significant at 10 percent; * significant at 5 percent; ** significant at 1 percent.
\end{abstract}

The baseline results in column 1 provide consistently positive effects for the share of independent-school students on the educational outcome variables. A 10 percentage point increase in the share of independent-school students in compulsory school is associated with 1.7 percentile rank higher achievement at the end of compulsory school. Interestingly, the effects also remain positive and significant after compulsory school. A 10 percentage point 
increase in the share of independent-school students increase the fraction with an academic track in high school by 2 percentage point, the mean high-school grades with 2 percentile rank, the fraction attending university by almost 2 percentage points and the average years of schooling by almost 4 weeks. ${ }^{27}$ If we convert these estimates to effect sizes, we find that a 10 percentage point increase in the share of independent-school students increase both the shortand long-run outcomes by about $4-5 \%$ of a S.D. ${ }^{28}$

In column 2 we extend the baseline specification by adding changes in the municipality averages of demographic and family background controls over time. ${ }^{29}$ It is notable how much these variables increase the share of explained variation in the outcome variables (for instance, $\mathrm{R}^{2}$ increases from 0.08 to 0.28 for grades) at the same time as they barely affect the magnitude of the estimates. We conclude, first, that the estimates are unaffected by composition bias and, second, that any remaining bias in the estimates after these controls are added must be due to factors not captured by these variables.

We report estimates from model (3) in columns 3 and 4 of Table 2. Reassuringly, these estimates are typically small and statistically insignificant. Hence, we find no evidence that independent-school enrolment has increased more in municipalities where the educational performance of public school students changed a lot during the last five pre-reform years. This result is very important because one might expect independent schools to primarily be established in municipalities with failing public schools. Reassuringly, nothing in these estimations supports this assertion. This finding is also consistent with what we learned from our interviews with the four leading school companies running independent schools in Sweden. The performance in public schools was considered to be a criterion for opening up a new school by only one out of the four school companies, and it was ranked as a less important one. ${ }^{30}$ We have also, in addition to running these counterfactual estimations, simply

\footnotetext{
${ }^{27}$ In Böhlmark and Lindahl (2008) we in addition used the outcomes "Observed with grade marks from $9^{\text {th }}$ grade", "Observed with grade marks from high school" and "GPA at end of $3^{\text {rd }}$ year in high school (if academic track=1)". If we use these outcomes in model (2) we get the following estimates, respectively: $0.005(0.014) ; 0.016(0.112) ; 13.70(5.82)$. It is interesting to note that effect on "GPA at end of $3^{\text {rd }}$ year in high school" for the selective group of students who choose an academic high-school track is of similar size as for the other grade outcomes that are based on (almost) all students at the compulsory level and the $1^{\text {st }}$ year in high school. We also note that there are no statistically significant effects on the probability of being observed with grades at the compulsory level or at high school.

${ }^{28}$ We convert the estimates in column 2 of Table 2 to standard deviation (S.D.) units by dividing the estimate by the S.D of the variables (using the variation across all individuals as reported in Table 1). However, as the estimates for grades and test scores are scaled into percentile ranks we first need to apply the inverse of the standard normal distribution to convert the percentile rank to a point on the standard normal distribution. These resulting effect sizes (reported in the text) are about $60 \%$ of those obtained by simply dividing the estimates with the standard deviation.

${ }^{29}$ The most important controls are typically the change in the fraction of students that are immigrants and the change in the average years of schooling of fathers.

${ }^{30}$ We performed interviews with leading representatives for the 4 largest Swedish school corporations at the compulsory level (Kunskapsskolan; Vittra; Pysslingen; Ultra). We asked what municipal characteristics are important when they consider opening up a new independent school. The answers we got clearly point at two main factors. The attitudes to independent schools among local politicians' and voters' are considered as most important. The second main factor is the potential market share in the municipality, as determined by the size of existing public schools, population density and the number and size of existing independent schools.
} 
included the change in the grades between 1988 and 1992 as an additional control variable in estimation of model (2). When this is done, the estimates remain virtually unchanged.

\section{Further analysis}

\subsection{Sensitivity analysis}

Although we have already seen that our estimates are not driven by composition bias or by differential pre-reform trends, we now investigate a number of other issues that might affect the credibility of our estimates. We first consider differential grade inflation, and present results in table 3 . We than consider other issues, where we report the baseline estimates in column 1 of Table 4 and Table 5 (identical to the estimates reported in column 2 of Table 2) and then sequentially report the estimates from alternative specifications and models.

Differential grade inflation In Sweden, the average grade scores determine admittance to specific high school programs whenever there is an excess demand for slots. Although the scores on the national standardized tests guide the teachers' grade setting in some core subjects (math, English and Swedish), the concern is that differential grading standards might have developed in municipalities with more or fewer independent schools. We might expect the schools to compete for students not only with high-quality education but also by inflated grades. However, there are several reasons why we believe this is not important for the interpretation of our estimates. First, if differential grade inflation is important, we would expect to see larger estimates for grades than for test scores in our main estimations. It can be seen from Table 2 that the grade and the test score estimates are very similar. ${ }^{31}$ Second, if differential grade inflation drives our results at the end of compulsory school, they would be expected to fade in importance when looking at post-compulsory school outcomes. However, as is evident from Table 2, we find positive effects also for high school grades and university attendance. ${ }^{32}$ Third, because the standardized national tests were only given in some core subjects, we would expect grade inflation to be more severe for subjects without these tests.

\footnotetext{
${ }^{31}$ The National Agency for Education distribute national standardized tests as well as issue guidelines to teachers that spell out the specific criteria a pupil must meet in order to qualify for a certain score. Even if one can argue that even results on tests can be manipulated (as the tests are corrected locally), it is unreasonable to believe that it should be equally easy for teachers to cheat when correcting tests as it would be for them to set inflated grades.

${ }^{32}$ One might argue that also these effects could be indirectly affected by grade inflation at the end of compulsory school (as the prevalence of independent schools at the compulsory and high school level is positively correlated and if there exist grade inflation at the high school level). However, if we include the share of independent-school students at the high-school level as a control variable the estimates for postcompulsory school outcomes are unaffected.
} 
We therefore follow the same approach as in Vlachos (2010) and construct a measure of the difference between students' grade scores in subjects without national tests and grade scores in subjects with national tests. The idea behind this measure is that grades in subjects that have regular tests are determined using a more rigorous objective knowledge assessment than grades in subjects without these tests (in which the grades are determined using a more subjective assessment). It is reasonable to believe that the teacher in the latter type of subject more easily succumb to pressure to give generous grades than teachers in subjects where students' achievements are regularly tested. In order to test the hypothesis that this pressure on the teachers to set generous grades is stronger in areas with more school competition, we use the measure proposed in Vlachos (2010) as an outcome variable in model (2). The results are shown in Table 3.

Table 3: OLS Regressions of changes in the share of independent-school students on post-reform changes in overall grade inflation

(1)

(2)

$\underline{\text { Grade inflation outcome }}$

Difference between grades in practical

Controls

Changes in municipal controls ${ }^{\mathrm{a}}$

\section{YES}

Notes: ${ }^{a}$ Changes in municipality averages of demographic and family background variables: parents' earnings; parents' education; parents' age; immigrant status; parents' immigrant status; size of the student population (see Table 1 for details). Robust standard errors are in parentheses. + significant at 10 percent; * significant at 5 percent; ** significant at 1 percent.

We find a statistically insignificant association between the change in average "grade inflation" in the municipality between 1992 and 2009 and the change in the share of independent-school students between the same years. If anything, the negative point estimates indicate that there is less grade inflation in areas with more independent-school students. ${ }^{33} \mathrm{We}$ therefore conclude that differential grade inflation does not drive our positive results for

\footnotetext{
${ }^{33}$ This analysis is inspired by Vlachos (2010). Besides this measure of grade inflation, he also uses the difference between grades and test scores to analyze the issue whether school competition leads to grade inflation. He finds that there is no difference in grading standards between public and independent schools and that effects of competition from independent schools on grade inflation is positive but small. He concludes that this effect is so small that it can almost seem trivial. He stresses, however, that there is uncertainty due to the fact that there is no perfectly objective measure of knowledge to compare the grades with. The results in Vlachos (2010) are very much in line with what we find. The small differences that we can observe are potentially due to the fact that 1998 is the first year that is included in his analysis, whereas our analysis departures at 1992 which is the last pre-reform year.
} 
educational achievement outcomes. As we will see below (in section 7), this conclusion is further strengthened when we perform estimations using data from TIMSS.

Effects of choice between public schools In the early 1990s, choice among public schools became an additional option to students, parallel to the voucher reform with free choice between independent and public schools. In order to examine whether our estimated independent-school choice effects are confused with effects from choice between public schools, we constructed a variable that aims to capture this potential latter effect: the share of public school students who chose to attend another public school than the students living in the same neighbourhood (SAMS) typically attend. This variable is defined at the municipality level, and summary statistics are shown in the last panel of Table 1. Our measure indicates that as many as 13 percent opted for another public school in 1992, a number that is most certainly overstated due to measurement error. ${ }^{34}$ However, we note that this fraction was constant during the pre-reform years and if the measurement error remained constant in the post-reform period, it would be a municipality fixed effect and hence netted out in our regressions. We can note in the table that the share of students who opt out to another public school almost doubled between 1992 and 2009. This large increase is somewhat surprising since the students who live closest to the school have priority, and choice is restricted to empty slots.

Next, we add in our main regression model this control for changes in the degree of choice among public schools in the municipality. The results are reported in column 2 of Table 4. It is very comforting to see that the estimates are barely affected. We also note that the coefficient estimate (standard error) for the change in public school choice is 4.83 (2.57) for the test scores in column 2, indicating that an increase in public school choice has an independent positive effect on test scores. The corresponding estimates are all positive (and sometimes significant) for the other educational performance outcomes. ${ }^{35}$

\footnotetext{
${ }^{34}$ We cannot perfectly observe the share of students who choose another public school than the assigned neighboring school since we lack information about schools catchment areas. But we are able to construct a proxy variable based on the information on which neighborhood (SAMS-area) a pupil lives, the school he or she attends and the typical school attended among students who live in the same neighborhood. Admittedly, this variable is measured with error since the catchment areas of schools do not always overlap with neighborhoods. This is underlined by the fact that the share of students who attended another public school than the typical one before the reform (nearly 13 percent all 5 pre-reform years) is probably too high if the typical school always were the assigned school. However, we do expect this share to be greater than zero since individuals with very special reasons could get permission to change school also before the reform.

${ }^{35}$ The share of students actively choosing another public school is a variable (just as school expenditure per student which we include below) that is probably endogenous to the share of independent school students and is then a bad control variable in our regressions. However, we include it as a sensitivity check anyway to see if the coefficient estimate for the share of independent school pupils change compare to when it is not included. If estimates are unchanged we infer that the evolution of the share of independent school pupils and the share of public school students making an active choice are weakly enough associated so as to not affect the estimate for the share of independent school pupils. Of course, we have no way of knowing what the evolution of the share of independent school pupils would have been have choice between public schools not been allowed.
} 
Effects of school decentralization Another major change that occurred in Swedish compulsory education in the early 1990s was the decentralization of schooling from the state to the municipalities. The municipal governments were responsible for the supply of compulsory education before this reform as well, but schooling was tightly regulated by the central authorities. Following the decentralization reform, the municipalities were given much more freedom over funding and organization. The central authorities set targets for compulsory school, but the municipal authorities have much freedom in how to reach these goals. We have shown that the pre-reform trends in student achievement were similar across municipalities irrespective of subsequent differential changes in independent schooling. One might argue that such parallel trends are expected in a strictly centralized school system in the absence of major compositional changes over time, but this result is reassuring for our identification strategy nonetheless.

The worry with the decentralisation reform is that some municipalities might have begun to invest more in their schools and became better equipped to operate schools compared to other municipalities after the reform and that this also impacts the differential change in independent schooling across municipalities. However, it is important to note that if the management of public schools is affected by an increase in the share of independent school students this is a mechanism and something we want our estimates to reflect. Bias could arise if changes in management affect the changes in outcomes as well as changes in independent schooling within municipalities. A downward bias is expected if larger fractions of students choose independent schools in municipalities where the quality of public schools is falling due to poorer management over time by the local government. A downward bias is also expected if a smaller fraction of students choose independent schools as a consequence of successful management of public schools that is due to potential, but not realized, competition from independent schools. A positive bias is expected if municipality governments that improve their management of their schools also tend to actively encourage competition from independent schools.

We first consider the potential issue of changes in management practices that generates differences in investments per student. We have data on how much each municipality spends on compulsory schooling per student each year between 1993 and 2009. The summary statistics for this variable are shown in the last panel of Table 1 (see the note to Table 8 for a description of this measure). We observe that "school expenditures per pupil" has increased substantially in real terms over time but that the dispersion between municipalities is, surprisingly, virtually unchanged. We then add this control for changes in the municipal 
school expenditures per pupil to the main regression model in an effort to control for the consequences of the decentralization of school financing. The estimates, shown in column 3 of Table 4, are largely unaffected. This finding is very reassuring.

We next consider the possibility that changes in the ability of local authorities to operate schools not only is reflected in changes in spending per student. ${ }^{36}$ First, we note that if the decentralization reform has yielded differential trends in management ability that are also impacting the differential increase in independent schooling, we expect our baseline estimates to be affected when we control for changes in the municipalities' compositions. As was shown in Table 2, the estimates remain very similar when we add a detailed set of controls that substantially increase the share of explained variation in the outcome variables. As we will see below, the estimates are also not sensitive to controlling for political majority variables or for variables measuring initial (pre-reform) compositional differences between municipalities. Second, the estimates are similar when we use measures of the potential market opportunities in the municipality, as determined before the reform, to instrument the share of independent school students (see below). This finding indicates that unless potential market opportunities are correlated with the consequences of decentralization, any effects of decentralization do not bias our main estimates. Third, when we control for county fixed effects, our baseline estimates are not substantially affected. Because decentralization effects are likely to be more similar within counties than between counties, this finding provides further support that such possible effects are not of great importance in our baseline estimates. The robustness of the results makes us much less worried about the potential influence from unobserved decentralization effects.

Endogenous policy response Non-socialist local governments are generally friendlier toward independent schools than socialist local governments. This is a fixed effect in municipalities with stable majorities, but possible changes in opinions can be proxied for by controlling for changes in the local political majority. Note that political majority shifts are also potentially endogenous since establishing independent schools might impact voting behaviour. In column 4 we show what happens to the estimates if we add a control for changes in political majority. We find that the baseline estimates remain unchanged.

\footnotetext{
${ }^{36}$ One example of such change might be in the ability to hire good principals and improve the screening of new teachers in schools. This is something that might have become increasingly important over time as there has been a decline since the early 1990s in new subject teachers' cognitive and social abilities as well as in their high school GPAs (see, Grönqvist and Vlachos, 2008).
} 
Table 4 Regressions of changes in the share of independent-school students on changes in overall educational achievement, robustness checks I

\begin{tabular}{|c|c|c|c|c|c|c|c|c|}
\hline \multicolumn{9}{|l|}{ Number of municipalities: 284} \\
\hline & (1) & (2) & (3) & (4) & (5) & (6) & $(7)^{b}$ & $(8)^{\mathrm{c}}$ \\
\hline Educational outcomes: & OLS & OLS & OLS & OLS & OLS & $\begin{array}{l}\text { IV: Share of indep. } \\
\text { schools }\end{array}$ & $\begin{array}{l}\text { IV: } 1992 \text { market } \\
\text { opportunities I }\end{array}$ & $\begin{array}{l}\text { IV: } 1992 \text { market } \\
\text { opportunities II }\end{array}$ \\
\hline Test scores in English and math & $\begin{array}{c}17.93 \\
(2.69)^{* *}\end{array}$ & $\begin{array}{c}16.66 \\
(2.58)^{* *}\end{array}$ & $\begin{array}{c}17.79 \\
(2.70)^{* *}\end{array}$ & $\begin{array}{c}17.76 \\
(2.68)^{* *}\end{array}$ & $\begin{array}{c}13.65 \\
(3.07)^{* *}\end{array}$ & $\begin{array}{c}24.05 \\
(5.36)^{* *}\end{array}$ & $\begin{array}{c}18.16 \\
(12.65)\end{array}$ & $\begin{array}{c}22.74 \\
(11.07)^{*}\end{array}$ \\
\hline $\mathrm{R} 2$ & 0.28 & 0.30 & 0.31 & 0.29 & 0.34 & $\mathrm{~F}^{\text {first stage }}=145.99$ & $\mathrm{~F}^{\text {first stage }}=8.77$ & $\mathrm{~F}^{\text {first stage }}=4.94$ \\
\hline Grades in English and math & $\begin{array}{c}15.76 \\
(2.55)^{* *}\end{array}$ & $\begin{array}{c}15.09 \\
(2.50)^{* *}\end{array}$ & $\begin{array}{c}15.57 \\
(2.58) * *\end{array}$ & $\begin{array}{c}15.56 \\
(2.52)^{* *}\end{array}$ & $\begin{array}{c}14.48 \\
(2.89)^{* *}\end{array}$ & $\begin{array}{c}20.12 \\
(5.66)^{* *}\end{array}$ & $\begin{array}{c}7.63 \\
(15.63)\end{array}$ & $\begin{array}{c}17.62 \\
(10.30)+\end{array}$ \\
\hline $\mathrm{R} 2$ & 0.28 & 0.28 & 0.30 & 0.30 & 0.33 & $\mathrm{~F}^{\text {first stage }}=145.99$ & $\mathrm{~F}^{\text {first stage }}=8.77$ & $\mathrm{~F}^{\text {first stage }}=4.94$ \\
\hline Academic track in high school & $\begin{array}{c}0.19 \\
(0.13) \\
0.07\end{array}$ & $\begin{array}{c}0.20 \\
(0.14) \\
0.07\end{array}$ & $\begin{array}{c}0.17 \\
(0.13) \\
0.10\end{array}$ & $\begin{array}{c}0.19 \\
(0.13) \\
0.07\end{array}$ & $\begin{array}{c}0.11 \\
(0.14) \\
0.12\end{array}$ & $\begin{array}{c}0.22 \\
(0.25) \\
\mathrm{F}^{\text {first stage }}=130.35\end{array}$ & $\begin{array}{c}0.04 \\
(0.45) \\
F^{\text {first stage }}=24.03\end{array}$ & $\begin{array}{c}0.29 \\
(0.44) \\
\mathrm{F}^{\text {first stage }}=10.89\end{array}$ \\
\hline $\begin{array}{l}\text { Grades in } 1^{\text {st }} \text {-year courses in } \\
\text { English and math in high school } \\
\text { R2 }\end{array}$ & $\begin{array}{c}17.47 \\
(3.83)^{* *} \\
0.17\end{array}$ & $\begin{array}{c}16.87 \\
(3.93) * * \\
0.17\end{array}$ & $\begin{array}{c}17.07 \\
(3.81)^{* *} \\
0.17\end{array}$ & $\begin{array}{c}17.45 \\
(3.80)^{* *} \\
0.18\end{array}$ & $\begin{array}{c}14.84 \\
(3.97)^{* *} \\
0.24\end{array}$ & $\begin{array}{c}23.44 \\
(8.74)^{* *} \\
\mathrm{~F}^{\text {first stage }}=130.35\end{array}$ & $\begin{array}{c}22.37 \\
(12.47)+ \\
\mathrm{F}^{\text {first stage }}=24.03\end{array}$ & $\begin{array}{c}25.12 \\
(11.84)^{*} \\
\mathrm{~F}^{\text {first stage }}=10.89\end{array}$ \\
\hline $\begin{array}{l}\text { At least } 1 \text { semester of university } \\
\text { studies at age } 22 \\
\text { R2 }\end{array}$ & $\begin{array}{c}0.19 \\
(0.06)^{* *} \\
0.17\end{array}$ & $\begin{array}{c}0.20 \\
(0.06) * * \\
0.17\end{array}$ & $\begin{array}{c}0.19 \\
(0.06)^{* *} \\
0.17\end{array}$ & $\begin{array}{c}0.20 \\
(0.06)^{* *} \\
0.18\end{array}$ & $\begin{array}{c}0.18 \\
(0.06)^{* *} \\
0.27\end{array}$ & $\begin{array}{c}0.11 \\
(0.18) \\
\mathrm{F}^{\text {first stage }}=50.15\end{array}$ & $\begin{array}{c}0.12 \\
(0.22) \\
\mathrm{F}^{\text {first stage }}=33.46\end{array}$ & $\begin{array}{c}0.22 \\
(0.19) \\
\mathrm{F}^{\text {first stage }}=14.60\end{array}$ \\
\hline Years of schooling at age 24 & $\begin{array}{c}0.64 \\
(0.35)+ \\
0.17\end{array}$ & $\begin{array}{c}0.67 \\
(0.36)+ \\
0.17\end{array}$ & $\begin{array}{c}0.63 \\
(0.34)+ \\
0.17\end{array}$ & $\begin{array}{c}0.65 \\
(0.35)+ \\
0.17\end{array}$ & $\begin{array}{c}0.82 \\
(0.42)^{*} \\
0.26\end{array}$ & $\begin{array}{c}0.95 \\
(0.81) \\
\mathrm{F}^{\text {first stage }}=86.40\end{array}$ & $\begin{array}{c}-0.09 \\
(1.81) \\
\mathrm{F}^{\text {first stage }}=9.13\end{array}$ & $\begin{array}{c}0.18 \\
(1.08) \\
\mathrm{F}^{\text {first stage }}=10.77\end{array}$ \\
\hline \begin{tabular}{l}
\multicolumn{1}{c}{ Controls } \\
Changes in municipal controls \\
Changes in public school choice \\
Changes in school costs \\
Shifts in political majority \\
1992 level of municipal controls
\end{tabular} & $\begin{array}{l}\text { YES } \\
\text { NO } \\
\text { NO } \\
\text { NO } \\
\text { NO }\end{array}$ & $\begin{array}{l}\text { YES } \\
\text { YES } \\
\text { NO } \\
\text { NO } \\
\text { NO }\end{array}$ & $\begin{array}{l}\text { YES } \\
\text { NO } \\
\text { YES } \\
\text { NO } \\
\text { NO }\end{array}$ & $\begin{array}{l}\text { YES } \\
\text { NO } \\
\text { NO } \\
\text { YES } \\
\text { NO }\end{array}$ & $\begin{array}{l}\text { YES } \\
\text { NO } \\
\text { NO } \\
\text { NO } \\
\text { YES }\end{array}$ & $\begin{array}{l}\text { YES } \\
\text { NO } \\
\text { NO } \\
\text { NO } \\
\text { NO }\end{array}$ & $\begin{array}{l}\text { YES } \\
\text { NO } \\
\text { NO } \\
\text { NO } \\
\text { NO }\end{array}$ & $\begin{array}{l}\text { YES } \\
\text { NO } \\
\text { NO } \\
\text { NO } \\
\text { NO }\end{array}$ \\
\hline
\end{tabular}

Notes: a Changes in municipality averages of demographic and family background variables: parents' earnings; parents' education; parents' age; immigrant status; parents' immigrant status; size of the student population (see Table 1 for details). ${ }^{b}$ The 1992 Market opportunities variable used as instruments in column (7) is: Pre-reform student base in $1992 .{ }^{\circ}$ The 1992 Market opportunities variables used as instruments in column (8) are: Pre-reform student base in 1992; Private school in municipality in 1992; More than one public school in 1992. Robust standard errors are in parentheses. + significant at 10 percent; * significant at 5 percent; ** significant at 1 percent. 
Table 5 Regressions of changes in the share of independent-school students on changes in overall educational achievement, robustness checks II

\begin{tabular}{|c|c|c|c|c|c|c|c|c|c|c|}
\hline & $(1)$ & $(2)$ & (3) & $(4)$ & (5) & (6) & $(7)$ & $(8)$ & $(9)$ & $(10)$ \\
\hline Educational outcomes: & Baseline & $\begin{array}{l}\text { Pre-reform } \\
\text { share of } \\
\text { private } \\
\text { students } \\
\text { control } \\
\end{array}$ & $\begin{array}{l}\text { Changes } \\
1993-2009\end{array}$ & $\begin{array}{l}\text { Only munic. } \\
\text { with no } \\
\text { private school } \\
\text { before the } \\
\text { reform }\end{array}$ & $\begin{array}{l}\text { Only munic. } \\
\text { with } \\
\text { independent } \\
\text { schools in } \\
2009 \\
\end{array}$ & $\begin{array}{l}\text { Local labor- } \\
\text { market } \\
\text { estimation }\end{array}$ & $\begin{array}{c}\text { County-level } \\
\text { estimation }\end{array}$ & $\begin{array}{l}\text { Weighted } \\
\text { estimation }\end{array}$ & $\begin{array}{l}\text { Pre-reform } \\
\text { level of } \\
\text { controls } \\
\text { including } \\
\text { GPA } \\
\end{array}$ & $\begin{array}{l}\text { Pre-reform } \\
\text { level of } \\
\text { controls } \\
\text { + Including } \\
\text { county-FE } \\
\end{array}$ \\
\hline $\begin{array}{l}\text { Test scores in English and } \\
\text { Math }\end{array}$ & $\begin{array}{c}17.93 \\
(2.69)^{* *}\end{array}$ & $\begin{array}{c}17.33 \\
(2.76) * *\end{array}$ & $\begin{array}{c}17.28 \\
(3.07)^{* *}\end{array}$ & $\begin{array}{c}17.90 \\
(2.99)^{* *}\end{array}$ & $\begin{array}{c}14.28 \\
(3.15)^{* *}\end{array}$ & $\begin{array}{c}16.50 \\
(6.09)^{* *}\end{array}$ & $\begin{array}{c}21.93 \\
(6.25)^{* *}\end{array}$ & $\begin{array}{c}14.47 \\
(2.17)^{* *}\end{array}$ & $\begin{array}{c}8.57 \\
(2.61)^{* *}\end{array}$ & $\begin{array}{c}9.40 \\
(3.43)^{* *}\end{array}$ \\
\hline $\mathrm{R} 2$ & 0.28 & 0.28 & 0.34 & 0.27 & 0.42 & 0.20 & 0.32 & 0.49 & 0.59 & 0.43 \\
\hline Grades in English and math & $\begin{array}{c}15.76 \\
(2.55)^{* *}\end{array}$ & $\begin{array}{c}14.94 \\
(2.54)^{* *}\end{array}$ & $\begin{array}{c}16.99 \\
(2.93)^{* *}\end{array}$ & $\begin{array}{c}16.03 \\
(2.90)^{* *}\end{array}$ & $\begin{array}{c}14.37 \\
(2.91)^{* *}\end{array}$ & $\begin{array}{c}14.34 \\
(5.32)^{* *}\end{array}$ & $\begin{array}{c}18.52 \\
(6.42)^{* *}\end{array}$ & $\begin{array}{c}12.96 \\
(2.02)^{* *}\end{array}$ & $\begin{array}{c}9.20 \\
(2.35)^{* *}\end{array}$ & $\begin{array}{c}11.03 \\
(3.17)^{* *}\end{array}$ \\
\hline $\mathrm{R} 2$ & 0.28 & 0.28 & 0.35 & 0.27 & 0.40 & 0.22 & 0.25 & 0.47 & 0.64 & 0.43 \\
\hline Academic track in high school & $\begin{array}{c}0.19 \\
(0.13)\end{array}$ & $\begin{array}{c}0.18 \\
(0.14)\end{array}$ & $\begin{array}{c}0.19 \\
(0.13)\end{array}$ & $\begin{array}{c}0.12 \\
(0.16)\end{array}$ & $\begin{array}{c}0.17 \\
(0.17)\end{array}$ & $\begin{array}{c}0.09 \\
(0.24)\end{array}$ & $\begin{array}{c}0.80 \\
(0.27)^{* *}\end{array}$ & $\begin{array}{c}0.14 \\
(0.16)\end{array}$ & $\begin{array}{c}0.10 \\
(0.14)\end{array}$ & $\begin{array}{c}0.05 \\
(0.15)\end{array}$ \\
\hline $\mathrm{R} 2$ & 0.07 & 0.07 & 0.07 & 0.06 & 0.14 & 0.14 & 0.27 & 0.17 & 0.12 & 0.20 \\
\hline $\begin{array}{l}\text { Grades in } 1^{\text {st }} \text {-year courses in } \\
\text { English and math in high school } \\
\text { R2 }\end{array}$ & $\begin{array}{c}17.47 \\
(3.83)^{* *} \\
0.17\end{array}$ & $\begin{array}{c}17.16 \\
(3.89)^{* *} \\
0.18\end{array}$ & $\begin{array}{c}17.51 \\
(3.86)^{* *} \\
0.16\end{array}$ & $\begin{array}{c}16.68 \\
(4.34)^{* *} \\
0.17\end{array}$ & $\begin{array}{c}16.12 \\
(4.40)^{* *} \\
0.30\end{array}$ & $\begin{array}{c}0.90 \\
(10.77) \\
0.29\end{array}$ & $\begin{array}{c}28.73 \\
(11.26)^{*} \\
0.17\end{array}$ & $\begin{array}{c}17.22 \\
(3.55)^{* *} \\
0.29\end{array}$ & $\begin{array}{c}15.05 \\
(4.08)^{* *} \\
0.24\end{array}$ & $\begin{array}{c}7.95 \\
(4.57)+ \\
0.34\end{array}$ \\
\hline $\begin{array}{l}\text { At least } 1 \text { semester of } \\
\text { university studies at age } 22 \\
\text { R2 }\end{array}$ & $\begin{array}{c}0.19 \\
(0.06)^{* *} \\
0.17\end{array}$ & $\begin{array}{c}0.21 \\
(0.07)^{* *} \\
0.18\end{array}$ & $\begin{array}{c}0.17 \\
(0.07)^{*} \\
0.09\end{array}$ & $\begin{array}{c}0.20 \\
(0.06)^{* *} \\
0.17\end{array}$ & $\begin{array}{c}0.19 \\
(0.06)^{* *} \\
0.32\end{array}$ & $\begin{array}{c}-0.12 \\
(0.17) \\
0.28\end{array}$ & $\begin{array}{c}0.35 \\
(0.14)^{*} \\
0.10\end{array}$ & $\begin{array}{c}0.20 \\
(0.05)^{* *} \\
0.26\end{array}$ & $\begin{array}{c}0.17 \\
(0.06)^{* *} \\
0.29\end{array}$ & $\begin{array}{c}0.11 \\
(0.07) \\
0.43\end{array}$ \\
\hline $\begin{array}{l}\text { Years of schooling at age } 24 \\
\text { R2 }\end{array}$ & $\begin{array}{c}0.64 \\
(0.35)+ \\
0.17\end{array}$ & $\begin{array}{c}0.66 \\
(0.43) \\
0.17\end{array}$ & $\begin{array}{c}0.35 \\
(0.64) \\
0.10\end{array}$ & $\begin{array}{c}0.59 \\
(0.40) \\
0.16\end{array}$ & $\begin{array}{c}0.71 \\
(0.39)+ \\
0.23\end{array}$ & $\begin{array}{c}0.86 \\
(0.93) \\
0.25\end{array}$ & $\begin{array}{c}1.64 \\
(0.77)^{*} \\
0.08\end{array}$ & $\begin{array}{c}0.60 \\
(0.35)+ \\
0.18\end{array}$ & $\begin{array}{c}0.75 \\
(0.45)+ \\
0.33\end{array}$ & $\begin{array}{c}0.49 \\
(0.42) \\
0.39\end{array}$ \\
\hline $\begin{array}{l}\text { Changes in municipal controls } \\
\text { Number of municipalities }\end{array}$ & $\begin{array}{l}\text { YES } \\
284\end{array}$ & $\begin{array}{l}\text { YES } \\
284\end{array}$ & $\begin{array}{l}\text { YES } \\
284\end{array}$ & $\begin{array}{l}\text { YES } \\
265\end{array}$ & $\begin{array}{l}\text { YES } \\
127\end{array}$ & $\begin{array}{l}\text { YES (LLM) } \\
109 \text { LLM }\end{array}$ & $\begin{array}{c}\text { NO } \\
24 \text { counties }\end{array}$ & $\begin{array}{l}\text { YES } \\
284\end{array}$ & $\begin{array}{l}\text { YES } \\
284\end{array}$ & $\begin{array}{l}\text { YES } \\
284\end{array}$ \\
\hline
\end{tabular}


Time-varying coefficients To arrive at equation (2) we need to assume that the coefficients in equation (1) are constant over time, which here means from the last pre-reform years in 1992 to the last post-reform years for which data are available (from 2001 and up to 2009 depending on the outcome analyzed). We might worry that the coefficients are not constant in (1) because we base the first differences on a long time period. If coefficients are not constant, we need to modify equation (2) to a model where we have added the control variables measured at the start of the period (i.e., in 1992, the last pre-reform year), generating the modified version of $(2):^{37}$

$$
\Delta \bar{Y}_{m}=\theta+\beta \Delta \bar{P}_{m}+\lambda \Delta \bar{X}_{m}+\varphi \bar{X}_{m, 0}+\Delta \varepsilon_{m}
$$

where $\bar{X}_{m, 0}$ denotes the measures of the characteristics of students residing in municipality $m$ in 1992 and its inclusion follows from allowing $\lambda_{t}$ to vary across cohorts. It is straightforward to add $\bar{X}_{m, 0}$ to the model that we estimate. The estimates, shown in column 5 of Table 4 , are slightly smaller for most outcomes, but never statistically different from the estimates reported in column $1 .^{38}$

Measurement error in the independent-school variable Even though we use register data of high quality, the fraction of students attending independent-schools might not be completely free from measurement error. To take this issue into account, we use the fraction of independent schools in a municipality (with stage 3 level compulsory school) as an instrument for the share of independent school students. Hence, this IV-estimate makes use of the variation in the change in the share of independent-school students that is due to changes in the share of independent schools between 1992 and the latest available post-reform year. ${ }^{39}$ This alternative measure of the size of the independent school sector in a municipality is more supply-side oriented and shifts only when new schools are opening up or old ones are closing down (and, hence, it is not affected by an increased demand for independent-school

\footnotetext{
${ }^{37}$ If we reformulate (1) with time-varying coefficients on the covariates, we get $\bar{Y}_{m t}=\gamma_{\mathrm{m}}+\alpha_{\mathrm{t}}+\beta_{\mathrm{t}} \bar{P}_{m t}+\lambda_{\mathrm{t}} \bar{X}_{m t}+\varepsilon_{\mathrm{mt}}$. Taking first differences then produce model (2') where $\theta$ is a constant and $\varphi=\lambda_{\mathrm{t}}-\lambda_{0}=\Delta \lambda$, so that if the impact of the covariates are unchanged over time we have that $\varphi=$ 0 . Since, the share of independent school students is zero in 1992, we have that $\beta_{t}=\beta$. Hence equation (2) is generated if $\varphi=0$. Note that $\bar{X}_{m, 0}$ is included in order to adjust for differences in baseline municipality characteristics before the reform was implemented, just like would be done in a difference-in-differences model where group characteristics differ before treatment.

${ }^{38}$ The municipality characteristics in 1992 that are the best predictors of the growth in the share of independent-school students between 1992 and 2009 are the fraction of parents with university education, the mean family income, the fraction of immigrants in the municipality and the size of municipality (all entering with positive sign). Notably, if we further add the level and change of average pupil achievement in public schools in the municipality prior to the reform among the X-variables, both are found to have no impact on the growth in the share of independent-school students.

${ }^{39}$ The share of independent schools is lagged three years in the estimations. Hence, we assume that students that leave compulsory school in year $t$ are affected by independent-school openings 3 years earlier. This is reasonable since if students switch schools, they typically do so at the start of stage 3 (i.e., grade level 7).
} 
slots given the existing independent schools). The exclusion restriction is that new independent schools should not affect educational performance over and above the impact on the share of students attending the independent schools. The estimates are shown in column 6 of Table 4. Although the size of the estimates mostly increases, they become less precise and are never statistically different from the OLS estimates in column $1 .^{40}$

Omitted variables We have already shown that observable characteristics and differential pre-reform trends in the outcome variables do not bias our estimates. However, there might be time-varying unobserved factors that cause shocks to the demand for independent-school slots, and these factors might also be correlated with average educational performance. However, if these factors are uncorrelated with historical supply determinants, the latter are valid instruments for the growth in the share of independent-school students. ${ }^{41}$ We use the following pre-reform variables, all aimed at capturing the opportunity to establish independent-schools in the municipality ("market opportunities"), as instruments for the postreform change in the share of independent-school students:

\section{i) A measure of "the density of students in relation to the density of public} schools" in the municipality prior to the reform. ${ }^{42}$ The arguments for why this measure will have a (positive) impact on the share of independent-school students are as follows: First, the independent-school companies should be more interested in opening up schools when the opportunity to attract students is higher, which is the case if the public schools are less prevalent in relation to the density of students in the municipality. This argument is supported from our interviews with the leading school companies. These companies considered the potential market share in the municipality to be one of two main factors that are important in the decision to open up a new school. Second, the Swedish National Agency for Education (NAE) which determines whether to allow

\footnotetext{
${ }^{40}$ The reduced form estimates are as follows (where the order of the outcomes is the same as in the table): 6.39 (1.35); 5.34 (1.51); 0.08 (0.05); 5.13 (1.69); $0.02(0.03) ; 0.12(0.09)$.

${ }^{41}$ A related situation is if changes in average educational performance in the earlier years after the reform (generated by some exogenous shock) affects the growth in the share of independent school students in the later years after the reform. However, by using instruments that are determined prior to the voucher reform, the generated IV estimates are not biased because of this (as these IV estimates only use the part of the variation in the change in the share of independent school students that is due to variation in these historical instruments). This is also likely to be more of an issue for the estimates using the longest possible post-reform period, compared to when we look at the period 19922001.

${ }^{42}$ Formally we calculate $Z_{m, 1992}=\sigma\left(\frac{\text { Pupils }}{\text { Area }}\right)-\sigma\left(\frac{\text { Schools }}{\text { Area }}\right)$ for each municipality, where Pupils is the number of pupils in $9^{\text {th }}$ grade in the municipality in 1992; Schools is the number of schools (with ninth grade level) in the municipality in 1992, and; Area is the squared meter distance of the municipality. By $\sigma($.$) we indicate that both the number of pupils per square meter and the number of schools per square meter$ is standardized with mean zero and standard deviation one (so that both metrics are expressed in the same units). Hence, $Z_{m, 1992}$ measures the density of pupils in relation to the density of schools in a municipality.
} 
independent schools to be established, will be more likely to allow a new school if there is a high density of students in relation to the number of existing schools.

ii) An indicator for whether there existed a private school in the municipality prior to the independent-school reform. The argument is that these schools could be (and often were) converted to voucher schools and hence that in such a municipality, independent schools are established much more quickly than in comparable municipalities without existing private schools.

iii) An indicator for whether there existed "more than one public school" in the municipality in 1992. The argument is that the NAE is instructed to not approve applications if a new school is expected to "have considerable negative consequences for the municipality." This situation is more likely to occur if only one public school exists, because these municipalities then would be at risk in terms of having to continue to run a single public school at a very high per-pupil cost (municipalities are obliged to provide public schooling so it is very unlikely that a sole public school would be forced to close down).

We argue that these instruments do shift the supply of independent schools differently across municipalities after the reform. First-stage estimates are shown in Table A1 in the appendix. We then perform IV-regressions using only "the density of students in relation to the density of public schools" variable as an instrument. The estimates are shown in column 7 of table 4 . We see that these estimates are always positive and always statistically indistinguishable from the OLS estimates in column 1. The estimates from the IV-regressions using all three prereform variables as instruments for the change in the share of independent-school students are reported in column 8 of table 4 . The estimates remain very similar. ${ }^{43}$

The private schools that already existed prior to the reform In our analysis, we associate the change in educational outcomes with the change in the share of independent-school students across municipalities. A few things are worth noting about the measures used: First, we have coded the share of independent-school students to zero in 1992. This coding is correct because independent schools did not then exist. However, biased estimates could arise from differential truncation of the achievement distribution before and after the reform (leading to composition bias). As a check for whether this bias is important, we included the

\footnotetext{
${ }^{43}$ It is possible that these instruments are invalid because they also have an impact on public school openings. However, when we as a control variable in the IV-regressions add a variable capturing the density of public schools (the number of public schools divided by the number of students in the municipality) the estimates remain unaffected.
} 
share of private school students in 1992 as a separate variable in equation (1) and, hence, estimated equation (2) with an added variable "the share of private school students in 1992." The resulting estimate for the share of independent-school students is shown in column 2 of Table 5. It can be seen that this estimate is unchanged compared to column 1 . The result is the same if we instead simply use the change in the share of all non-public school students as the main independent variable. Hence, the prevalence of pre-reform private schooling does not affect both the post-reform changes in private schooling and the change in the outcomes. Second, grades were not collected for private schools before 1993. Hence, the students in these schools (<1\% in 1992) are not included in the municipality grade averages in 1992 (but they are included in our other educational outcome measures.). This exclusion could give raise to composition bias. We therefore re-estimated model (2) using the year 1993 instead of 1992. The estimates remain unchanged (column 3 in Table 5). Lastly, we show results using only the sub-sample of municipalities where no private school existed before the reform (column 4). Again, the estimates remain very similar.

Only municipalities with independent-schools in 2009 One might argue that the municipalities without independent schools are fundamentally different from the municipalities with independent schools, or that the first independent school is what is important in generating competition effects. We therefore check the sensitivity of our results using only municipalities that have at least one independent school. As seen in column 5 of Table 5, the estimates remain very similar.

Effects across municipality borders We might underestimate the effects if there are spillover or competition effects across municipality borders. We might also worry about endogenous teacher mobility across borders, which might be expected as wages are found to be positively affected by the share of independent school students at the high-school level in Hensvik, 2012. This could have resulted in a change in the composition of teachers across municipalities which possibly affect the interpretation of our estimates. Hence, we switch the unit of analysis from the municipality to the local labor market (LLM) and county area levels. Using LLM area levels in estimating model (2), we see that some of the estimates decrease in magnitude (column 6 of Table 5). However, the standard errors double and triple in magnitude, and only the grade and test score estimates are statistically significant. Using 
county level instead gives somewhat bigger estimates (column 7 of Table 5). ${ }^{44}$ Given the imprecision of these estimates we are not able to say much about whether there exist spillover effects across municipality borders.

Weighted estimations So far we have given each municipality equal weight in our estimations. This is reasonable if we think of each municipality as a separate school market. However, this might also mean that our results could be driven by very small municipalities. We therefore perform estimations where we instead weight each municipality using the number of students as weights. We show these estimates in column 8 of Table 5 . As can be seen, estimates using WLS yield very similar results.

\section{Controlling for pre-reform mean of GPA in the municipality and for county-FE In an}

additional attempt to check the sensitivity of our results we i) control for the level of mean GPA (English and Math) in the municipality in 1992, just before the implementation of the school choice reform, and ii) include county fixed effects as controls. The baseline specification here is the one with post-reform changes in municipality controls as well as prereform level of controls (as in column 5 of Table 4 ). ${ }^{45}$ When we include the level of GPA in 1992 (column 9 of Table 5), we note that the $\mathrm{R}^{2}$ increases quite a lot for the outcomes measured at the end of compulsory school. The estimates for these short-term outcomes decreases somewhat, but remain highly statistically significant. It is worth noting that this specification is a lagged dependent variable model and as such sensitive to bias from measurement error in the student achievement measures and to bias from serially correlated regression errors. When we include 24 county fixed effects (column 10 of Table 5) we see that $\mathrm{R}^{2}$ increases quite a lot for all outcomes. Given that we now only use variation between municipalities within counties we are quite amazed that all estimates remain positive and that three of them are statistically significant. It is important to realize that by controlling for county fixed effects we throw away a lot of useful variation in the share of independent school students between municipalities (more precisely all the variation that exist between municipalities in different counties). In fact, only $53 \%$ of the variation in the change in the

\footnotetext{
${ }^{44}$ There are 24 counties in Sweden. Because of the small number of observations, we do not control for any covariates in the model underlying the estimates in column 7 of Table 4 . If we add changes in the background variables similar as in the other columns (but defined at the county level), most estimates are of similar size. However, the standard error increases a lot, making most estimates statistically insignificant.

${ }^{45}$ We thank a referee for suggesting the two specifications underlying the estimates shown in columns 9 and 10 of Table 5 . The estimates in column 9 become larger if we omit the pre-reform level of municipality controls (except mean GPA) and are mostly larger also compared to our baseline specification without mean GPA. The estimates in column 10 remain very similar if we do not include the pre-reform level of municipality controls for the estimates that are statistically significant from zero. For the variables with insignificant estimates (academic track in high school, university studies and years of schooling) the estimates become smaller (although they are still positive).
} 
share of independent school students is due to within-county variation. This does not only result in less precisely estimated effects but can also lead to severe downward bias due to measurement error. ${ }^{46} \mathrm{We}$ do therefore not consider this the main specification to be considered. Nevertheless, it is reassuring that the results hold up as well as they do in these estimations.

Heterogeneity over time So far, we have reported estimates from regressions using changes in variables calculated for the longest post-reform period possible. This makes sense since the share of independent-school students has increased throughout the whole period, giving rise to increased variation across municipalities over time, and because it probably takes time for the establishment of independent schools to impact overall educational performance. There are two main reasons for why we do not expect to find any effect closely after the reform in 1992. First, the variation in the changes in the share of independent school students is initially very low. Independent schools was really a marginal phenomenon the first half-decade after the reform, but in later years it has become a substantial fraction of the school sector in many municipalities. Second, the cohort that finished the $9^{\text {th }}$ grade in 2001 is the first fully treated cohort in the sense that they have spent all nine school years in the new system with school choice. Thus, we expect the estimated effect to increase over time, at least up until 2001, when each successive cohort gets more and more treatment in terms of school years in the new system. We might also expect larger effects over time after 2001 since the treatment intensity in terms of the incidence of independent schooling continues to increase over time. And we expect the estimates to become more precise over time as the variation gets larger.

Another potential reason for expecting a heterogeneity over time is that the composition of independent schools has changed, and different types of independent schools might have different impact on overall educational performance (they might differ in their efficiency as well as in the competitive pressure they put on public schools). Figure 3 displays how our estimates change over time when we estimate model 2 for different school cohorts. Since the precision is very low for the estimates in the early years after the reform, we combine the first four post-reform school cohorts (1993-1996) and label them partially treated cohorts 1 and the next four cohorts (1997-2000) and label them partially treated cohorts 2.

\footnotetext{
${ }^{46}$ See, e.g., the discussion about removing both good and bad variation in section 5.1 in Angrist and Pischke (2008).
} 
Figure 3: Estimates of model 2, heterogeneity over time.
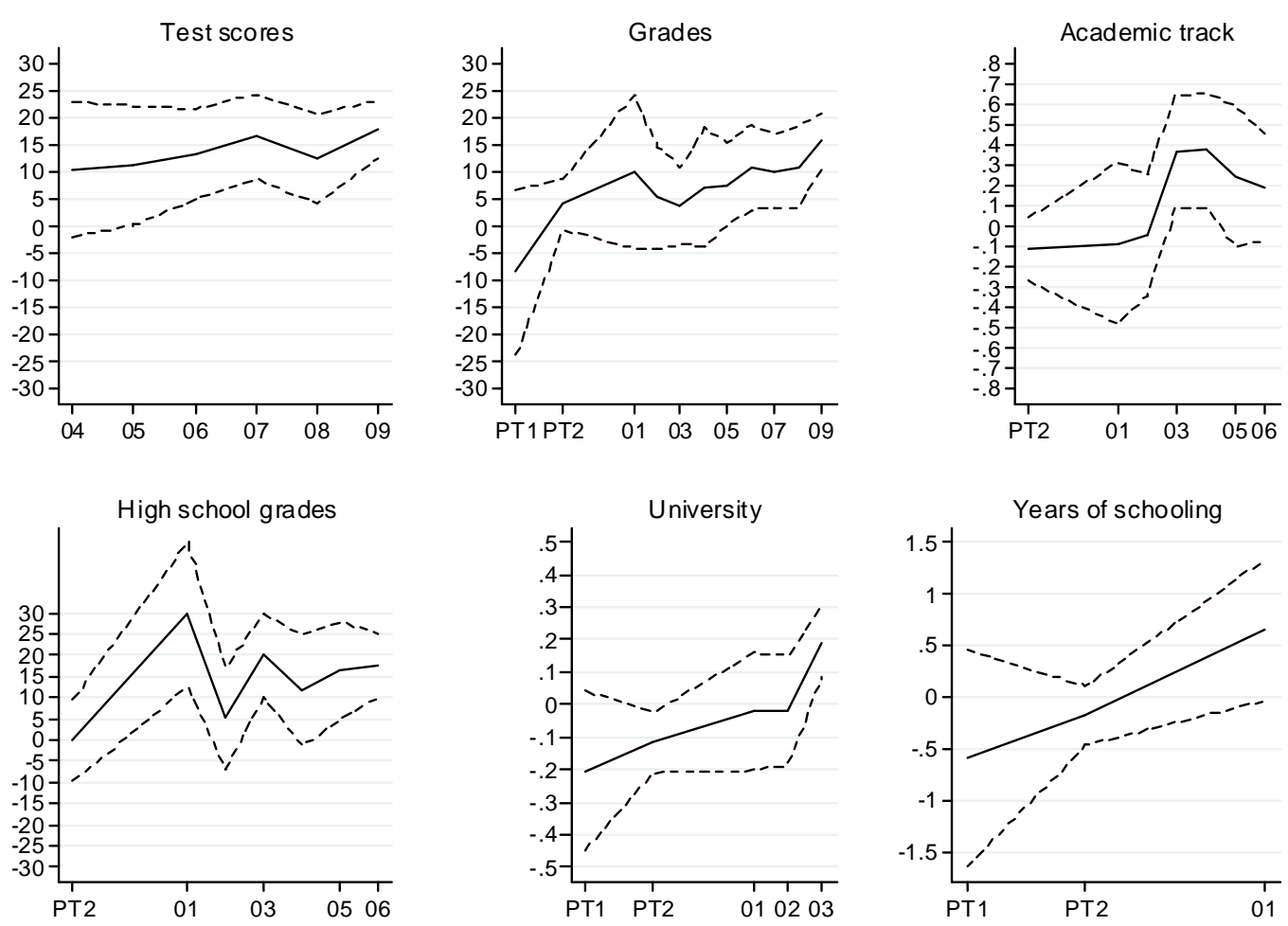

Note: The dashed lines are $95 \%$ confidence intervals. The estimates for the last school cohort for each outcome correspond to the ones presented in Table 2, column 2. PT1=partially treated cohorts 1; cohorts with 1-4 school years in the new system. PT2=partially treated cohorts 2; cohorts with 5-8 school years in the new system. The 2001 school cohort is the first cohort with all 9 years in the new system. For the two high-school outcomes, the estimates for PT1 are not shown since they are very imprecise. This follows from the fact that 1994 is the first year we have data for these two outcomes.

First, we can note that the estimates are very imprecise for many cohorts, and that the precision improves over time. Note here that the relatively good precision of the PT2 estimates is due to the fact that we use four cohorts in these estimations. Second, the estimates for the two $9^{\text {th }}$ grade outcomes are similar in size and increase somewhat between 2004 and 2009. If we consider grades in math and English (that we have for all years), we detect statistically significant effects 2005 and onwards. However, the impression is a relatively stable positive estimate from 2001 and onwards. In order to further examine when the effect on short-term outcomes first turn up, we have also performed weighted estimations. These estimates are more precise and turn out to be around 10 from 1998/1999 and onwards (this graph can be received upon request). Third, the two high school outcomes give a somewhat mixed picture. The grade outcome estimates are similar to the $9^{\text {th }}$ grade estimates, although they fluctuate a lot 2001-2002 (especially the estimate for 2001 is very imprecise). It is more uncertain if there is an effect on the probability of choosing an academic track. We find a significant positive effect 2003 and 2004 but not 2005 or 2006. Note, however, that all estimates for academic track are very imprecise. Finally, for the two long-term outcomes we 
detect statistically significant positive effects only for the very last years that we observe them, 2003 for university and 2001 for years of schooling. It might seem inconsistent that we find positive effects in the long term for the 2001 and 2003 cohorts when there are no statistically significant effects on grades in the $9^{\text {th }}$ grade for the very same cohorts. This is probably explained by the low precision of the grade estimates for these years (and the additional weighted estimations give support to positive short-term effects for these cohorts).

One might also argue that there is little support for long-term effects since these only are significant for the last cohorts, whereas the positive short-term effects are found for several cohorts. For example, if the last cohort for which we could have inferred effects for university studies would have been 2000 instead of 2001, we would have obtained an estimate around zero. We therefore conclude from this analysis that the overall evidence for long-term effects is weaker than for short- and medium-term effects, although we also note that the positive long-term effects turn up for about the same school cohorts that are the first to be observed with positive short-term effects.

To sum up, it becomes clear from these analyses that we do not find consistently positive estimates that are statistically different from zero until about a decade after the reform. ${ }^{47}$ At the same time, these findings are in line with the fact that the earlier schoolcohorts after the reform only are partially treated by the voucher system, as these cohorts all have less than 9 years in this system, and that it required time for independent schools to become more than a marginal phenomenon in Sweden. There are also other reasons for why we expect effects to take time to occur: the independent schools that existed the first few years after the reform were typically religious or special-pedagogy schools and it is not likely that these schools really were competing for the same students as the public schools; it probably takes time for public schools to respond in terms of organization and pedagogical techniques, and; a few regulatory changes took place after the first couple of years after the reform. ${ }^{48}$ Given all this, we would have been surprised to see sizable effects for the earliest school cohorts after the reform.

\footnotetext{
${ }^{47}$ In an earlier version of this paper (Böhlmark and Lindahl, 2008), we instead use all school cohorts and estimate equation (1) directly using individual level data (controlling for municipality fixed effects to take into account unobservable fixed municipality characteristics). In that paper, we were only able to use school cohorts until 2003 (for grades at the end of compulsory school and in high school), 2000 (university attendance) and 1998 (years of schooling). We then found positive effects only on short-run outcomes. If we use the same specification for the longer data periods in the present paper, we find positive estimates for all outcomes, but they are only statistically significantly different from zero for average test scores and grades at the end of compulsory school and for average high school grades.

${ }^{48}$ A new model for calculating the size of the voucher, and the formal abolishing of student fees were implemented starting with the academic year 1997/98.
} 


\subsection{Mechanisms}

\subsubsection{External effects}

Are the positive educational performance effects that we find only due to private benefits for students attending independent schools or are they also due to external benefits for students attending any type of school? We expect the latter to be important if, e.g., increased competition (and/or influx of new ideas) leads to improvements in the quality of public schools. We study this question in two ways. First, we look at the effects of an increase in the share of independent school students on the change in educational performance for the students in public schools. Second, we utilize our individual data to purge the overall effect from the average effect from attending an independent school.

Effects on public school students' performance It is very important to know if more independent schooling leads to better performance also in public schools or if the results are driven by improved performance for the students in independent schools. We therefore perform regressions using municipality level averages for educational performance calculated only for public school students. The results are reported in column 2 of Table 6 . The estimates decrease somewhat compared with the baseline estimates in column 1 , but they are still positive and statistically significant. The problem with these estimations is that they are likely to be tainted by sample selection bias because the share of public school students went from over $99 \%$ in 1992 to $89 \%$ in 2009. If the independent-school students would tend to be high performing students, we then expect the estimates to decrease if we only use public school students.

If students are influenced by the composition of their peer group, increased sorting of students can lead to problems in interpreting estimates of educational performance effects as effects on school productivity in the public schools. This issue is discussed in Hsieh and Urquiola (2006), who find that in Chile high-performing students are more likely to leave public schools when the private school share increased. There is some Swedish evidence that students who attend independent- and public schools differ along demographic- and family background characteristics (Björklund et al, 2005, Swedish National Agency for Education, 2003). However, we expect this to be of much less importance in Sweden than in the Chilean setting since Swedish schools are not allowed to select students at the compulsory level. We investigate the effect of the share of independent school students on sorting in Böhlmark and 
Lindahl (2007), and we find that public schools are more likely to lose students who are second-generation immigrants and/or whose parents have high education. However, we find no evidence of sorting of students by parental income and pupil's first generation immigrant status.

External effects across school sectors In essence, we can see $\beta$ in our baseline model (2) to capture two effects: the effect for the individual from attending an independent school and the external effect for the individual from the other students' independent-school attendance in the municipality. To estimate the magnitude of the external effect, we need to control for the effect for the individual from attending an independent school. To facilitate comparison with our earlier unweighted estimates, we choose to regress out the importance of the individual level variables in the following way: (1) using individual-level data, we separately regress each individual-level outcome, the municipal independent-school share and each municipallevel control, on a dummy for independent-school attendance and all individual-level controls for 2009 (or whatever the latest available school cohort is for the outcome); (2) using individual-level data we separately regress each individual-level outcome and each municipallevel control, on all individual-level controls for 1992 (recall that there were no independent schools in 1992); (3) we obtain the residuals from these regressions and aggregate them to the municipality-year level; (4) We take the difference between 2009 and 1992 for each municipality for all these residuals; (5) we regress model (2) separately for each outcome, using these residual changes as main variables.

The resulting estimates are shown in column 3 of Table 6 . The estimates are only somewhat smaller than the baseline estimates in column 1, but they are still mostly statistically significant. We conclude that approximately $70-80 \%$ of the overall effects of the share of independent school students on educational performance are due to external effects.

Although we realize the problem of estimating average effects of attending an independent school, we are quite confident that omitted individual variables do not seriously bias our estimates, and if they do, they are likely to make an estimate of the external effect a lower bound. First, the independent-school attendance effects decrease substantially when we add the demographic and family background variables to the estimation. Second, in Böhlmark and Lindahl (2007), we further find that independent-attendance estimates become even lower if we add family fixed effects to the model (hence only looking at the effects between siblings who differ in whether they attend an independent school). Third, the magnitude of our independent-school attendance effects are not very different from what was found in Ahlin 
(2005), who was able to estimate value-added models (controlling for student achievement at the end of the sixth grade) for students leaving compulsory school in 1998. Looking at the effects on math, English and Swedish test scores for a random sample of approximately 6000 students, she found effects ranging from insignificant zero or small positive effects up to 5 percentile ranks from attending an independent school in 1998.

Table 6 External effects from an increase in the share of independent-school students

\begin{tabular}{ccc}
\hline$(1)$ & $(2)$ & $(3)$ \\
\hline OLS: Baseline & OLS: Including only & OLS: External \\
public-school students & effects
\end{tabular}

Educational outcomes:

\begin{tabular}{|c|c|c|c|}
\hline $\begin{array}{l}\text { Test scores in English and } \\
\text { Math }\end{array}$ & $\begin{array}{c}17.93 \\
(2.69)^{* *}\end{array}$ & $\begin{array}{c}11.62 \\
(2.97)^{* *}\end{array}$ & $\begin{array}{c}15.28 \\
(2.85)^{* *}\end{array}$ \\
\hline $\mathrm{R} 2$ & 0.28 & 0.23 & 0.18 \\
\hline Grades in English and math & $\begin{array}{c}15.76 \\
(2.55)^{* *}\end{array}$ & $\begin{array}{c}9.53 \\
(2.82)^{* *}\end{array}$ & $\begin{array}{c}11.99 \\
(2.66) * *\end{array}$ \\
\hline $\mathrm{R} 2$ & 0.28 & 0.22 & 0.18 \\
\hline Academic track in high school & $\begin{array}{c}0.19 \\
(0.13)\end{array}$ & $\begin{array}{c}0.12 \\
(0.14)\end{array}$ & $\begin{array}{c}0.11 \\
(0.13)\end{array}$ \\
\hline $\mathrm{R} 2$ & 0.07 & 0.06 & 0.07 \\
\hline $\begin{array}{l}\text { Grades in } 1^{\text {st }} \text {-year courses in } \\
\text { English and math in high school } \\
\text { R2 }\end{array}$ & $\begin{array}{c}17.47 \\
(3.83)^{* *} \\
0.17\end{array}$ & $\begin{array}{c}13.18 \\
(4.42)^{* *} \\
0.14\end{array}$ & $\begin{array}{c}12.51 \\
(3.53)^{* *} \\
0.11\end{array}$ \\
\hline $\begin{array}{l}\text { At least } 1 \text { semester of } \\
\text { university studies at age } 22 \\
\text { R2 }\end{array}$ & $\begin{array}{c}0.19 \\
(0.06)^{* *} \\
0.17\end{array}$ & $\begin{array}{c}0.17 \\
(0.06)^{* *} \\
0.16\end{array}$ & $\begin{array}{c}0.16 \\
(0.06)^{* *} \\
0.10\end{array}$ \\
\hline $\begin{array}{l}\text { Years of schooling at age } 24 \\
\text { R2 }\end{array}$ & $\begin{array}{c}0.64 \\
(0.35)+ \\
0.17\end{array}$ & $\begin{array}{c}0.46 \\
(0.37) \\
0.15\end{array}$ & $\begin{array}{c}0.66 \\
(0.35)+ \\
0.11\end{array}$ \\
\hline $\begin{array}{l}\text { Controls } \\
\text { Changes in municipal controls } \\
\text { Number of municipalities }\end{array}$ & $\begin{array}{l}\text { YES } \\
284\end{array}$ & $\begin{array}{l}\text { YES } \\
284\end{array}$ & $\begin{array}{l}\text { YES } \\
284\end{array}$ \\
\hline
\end{tabular}

\subsubsection{Type of independent school}

One clear trend since the mid 1990s has been a strong growth in independent schools with a general profile and, in particular in for-profit independent schools with a general profile 
(especially during the 2000s). The independent schools that emerged in the early reform years might be regarded primarily as complements to the public schools. Because they attracted a rather special selection of students, the competitive pressure that these schools exerted is likely to have been modest. General-profile independent schools, however, are alternatives to the public schools and try to attract broad groups of students. The ownership structure might also be important in itself. Forward-looking owners of for-profit schools might develop successful and competitive schools to maximize their long-term profits. However, they might also start schools that turn out to be of low quality if their focus is on short-term profits. Nonprofit schools led by idealists do not have the same incentive to be cost efficient, but the idealistic nature of their business might form a good base for a competitive school.

Table 7 Regressions of changes in the share of students in for-profit, non-profit and general-profile independent schools on changes in overall educational achievement.

\begin{tabular}{|c|c|c|c|c|c|c|}
\hline & Test scores & Grades & $\begin{array}{c}\text { Academic } \\
\text { track in } \\
\text { high school }\end{array}$ & $\begin{array}{l}\text { High school } \\
\text { grades }\end{array}$ & University & $\begin{array}{c}\text { Years of } \\
\text { schooling }\end{array}$ \\
\hline & OLS & OLS & OLS & OLS & OLS & OLS \\
\hline $\begin{array}{l}\text { Share of students in for-profit- } \\
\text { general-profile indep. schools }\end{array}$ & $\begin{array}{c}21.46 \\
(4.19)^{* *}\end{array}$ & $\begin{array}{c}18.08 \\
(4.08) * *\end{array}$ & $\begin{array}{c}0.15 \\
(0.20)\end{array}$ & $\begin{array}{c}17.66 \\
(5.49) * *\end{array}$ & $\begin{array}{c}0.08 \\
(0.09)\end{array}$ & $\begin{array}{l}-0.16 \\
(0.45)\end{array}$ \\
\hline $\begin{array}{l}\text { Share of students in for-profit- } \\
\text { special-profile indep. schools }\end{array}$ & $\begin{array}{c}14.29 \\
(5.62)^{*}\end{array}$ & $\begin{array}{c}11.18 \\
(5.61)^{*}\end{array}$ & $\begin{array}{c}0.17 \\
(0.26)\end{array}$ & $\begin{array}{c}9.78 \\
(9.23)\end{array}$ & $\begin{array}{c}0.40 \\
(0.42)\end{array}$ & $\begin{array}{c}3.31 \\
(2.02)\end{array}$ \\
\hline $\begin{array}{l}\text { Share of students in non-profit- } \\
\text { general-profile indep. schools }\end{array}$ & $\begin{array}{c}12.13 \\
(6.58)+\end{array}$ & $\begin{array}{c}12.10 \\
(5.49) *\end{array}$ & $\begin{array}{c}0.21 \\
(0.12)+\end{array}$ & $\begin{array}{c}17.58 \\
(7.76)^{*}\end{array}$ & $\begin{array}{c}0.27 \\
(0.12)^{*}\end{array}$ & $\begin{array}{c}0.74 \\
(0.68)\end{array}$ \\
\hline $\begin{array}{l}\text { Share of students in non-profit- } \\
\text { special-profile indep. schools }\end{array}$ & $\begin{array}{c}23.35 \\
(8.12)^{* *}\end{array}$ & $\begin{array}{c}23.56 \\
(6.83)^{* *}\end{array}$ & $\begin{array}{c}0.40 \\
(0.37)\end{array}$ & $\begin{array}{c}29.61 \\
(10.71)^{* *}\end{array}$ & $\begin{array}{c}0.26 \\
(0.12)^{*}\end{array}$ & $\begin{array}{c}0.92 \\
(0.64)\end{array}$ \\
\hline \multicolumn{7}{|l|}{ Controls } \\
\hline Changes in municipal controls ${ }^{\mathrm{a}}$ & YES & YES & YES & YES & YES & YES \\
\hline $\mathrm{R} 2$ & 0.29 & 0.30 & 0.08 & 0.19 & 0.18 & 0.17 \\
\hline Number of municipalities & 284 & 284 & 284 & 284 & 284 & 284 \\
\hline
\end{tabular}

Notes: ${ }^{\text {a }}$ Changes in municipality averages of demographic and family background variables: parents' earnings; parents' education; parents' age; immigrant status; parents' immigrant status; size of the student population (see Table 1 for details). Robust standard errors are in parentheses. + significant at 10 percent; * significant at 5 percent; ** significant at 1 percent. In 2009 , the total share of students in independent school is about 0.11 . The shares for the respective category in the table for 2009 are as follows: $0.036^{\mathrm{b}} ; 0.034^{\mathrm{c}} ; 0.010^{\mathrm{d}} ; 0.027^{\mathrm{e}}$. For 2001 (we observe years of schooling for this school cohort), the corresponding shares are: $0.005^{\mathrm{b}} ; 0.004^{\mathrm{c}} ; 0.004^{\mathrm{d}} ; 0.018^{\mathrm{e}}$

Table 7 shows the estimates from regressions corresponding to those in column 2 of table 2, but in table 7 we have separated the share of independent-school students into four variables depending on the school type and ownership. We see that the separate estimates are 
not statistically different from one another. The conclusion that can be drawn from these estimates is that the independent school type and whether they are for or non-profit does not appear to matter much for the overall effect on students in both public and independent schools. $^{49}$

\subsection{School costs}

We are ultimately interested in the effects on school productivity, i.e., output per unit spent. So far we have only looked at output (the numerator). Now we look at costs (the denominator in the school productivity measure). The sign of an estimate of the effect of the share of independent-school students on school costs is ambiguous. On the one hand, increased competition can force schools to operate more efficiently and thereby lower their costs. For example, the fact that many independent schools (and school companies) are able to make profits year after year and still attract increasing numbers of students might work as a signal to the public sector that it is possible to run schools more efficiently (recall that the size of the voucher is determined by the costs in the public sector). On the other hand, if the schools that lose many students do not close down, the costs will increase because each school has fixed costs, e.g. for buildings, that are independent of the number of students attending them. It is, for example, possible that the local governments for various reasons (e.g., ideological) provide additional resources to the threatened public schools, leading to an over-capacity in the school sector. It is also possible that the local authorities who are in favor of school choice and competition invest additional resources in all schools to stimulate fair competition among them. The largest part of school expenditures are made up of personnel costs. Hensvik (2012) examines how local school competition affects teacher wages at the high-school level. She finds that the effect on average wages is modest, but that it leads to a more differentiated wage setting for the teachers (in both independent and public schools).

To examine the impact of the share of independent-school students on school costs, we estimate the following model:

$$
\Delta \log [\text { Expenditures/student }]_{\mathrm{m}}=\kappa_{0}+\kappa_{1} \Delta \bar{P}_{\mathrm{m}}+\kappa_{2} \Delta \bar{X}_{\mathrm{m}}+\nu_{\mathrm{m}}
$$

\footnotetext{
${ }^{49}$ There is one Swedish study that has attempted to estimate educational achievement effects of attending a for-profit independent school. Sahlgren (2010) use Swedish school-level data for the years 2005-2009 and estimate OLS models where average GPA is regressed on indicators for school type and demographic, family background and school level variables. He finds a positive association between average GPA and being a for-profit and non-profit independent school, where the latter coefficient estimates are of similar size.
} 
where the outcome variable is the change in the logarithm of total school expenditures per student (based on the students residing in the municipality but attending a school in any municipality) between 1992 and 2009, and other notations are as before.

Table 8 Regressions of changes in the share of independent-school students on changes in log expenditures per student

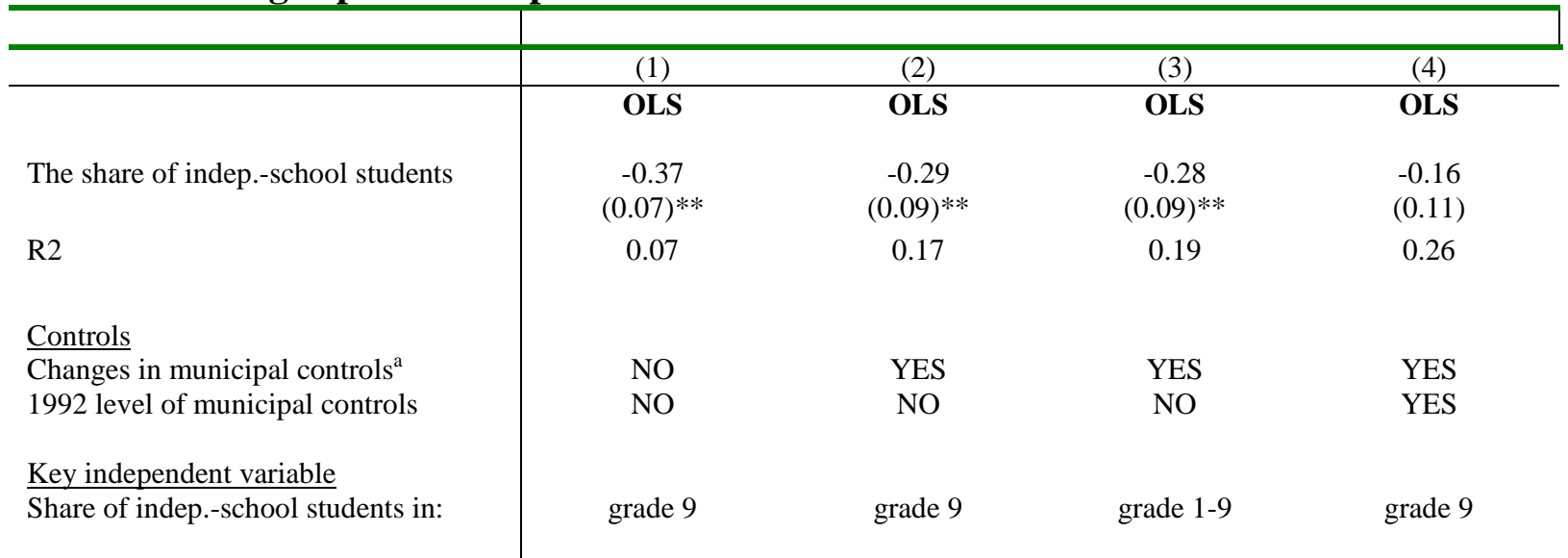

Notes: ${ }^{\text {a }}$ Changes in municipality averages of demographic and family background variables: parents' earnings; parents' education; parents' age; immigrant status; parents' immigrant status; size of the student population (see Table 1 for details. Robust standard errors are in parentheses. + significant at 10 percent; * significant at 5 percent; ** significant at 1 percent. Expenditures per student are calculated for students residing in the municipality, but who can attend a school in any municipality. Revenues from students living in another municipality but who attend a school in the municipality are deducted. It is total school expenditures, hence including personnel costs, rent costs, teaching materials, school meals, libraries, etc. The data on expenditures per student was downloaded from the Swedish National Agency for Education's homepage: http://www.skolverket.se/statistik-och-analys/2.1862/2.4290/2.4294. A detailed documentation of this data is also available at their homepage.

The results are reported in Table 8 (see the table note for a description of the cost data). We find statistically significant negative effects, regardless of whether we control or changes in background variables. ${ }^{50}$ If the share of independent-school students increases by 10 percentage points, overall school expenditures decreases by 3 percent. However, the estimates are sensitive to controls for initial characteristics. As seen in column 4, the estimate then becomes insignificant (although still negative). The data on school expenditures are only available for grades 1-9 taken together. For this reason, in column 3, we use the alternative measure of the share of independent school students in grades 1-9. We note that this makes no difference. ${ }^{51}$ We conclude that there is no evidence that school expenditures increase as a result of an increase in the share of independent-school students. This conclusion is further strengthened by the time pattern of these estimates, displayed in Figure 5. It should be noted, however, that private capital investments by owners of independent schools are not included

\footnotetext{
${ }^{50}$ Björklund et al. (2005) estimate the relationship between the change in total school costs per student and the change in private school share in grades 1-9 between the years 1992 and 2001, controlling for some covariates. They find a positive but statistically insignificant effect. Their estimate is 0.14 , with a standard error of 0.72 .

${ }^{51}$ If we chose to use student-population weights when estimating equation 4, results remain very similar.
} 
in our measure of expenditures. Hence, the total school expenditures might be somewhat underestimated in municipalities with independent schools.

Figure 5: Estimates of model 4', heterogeneity over time.

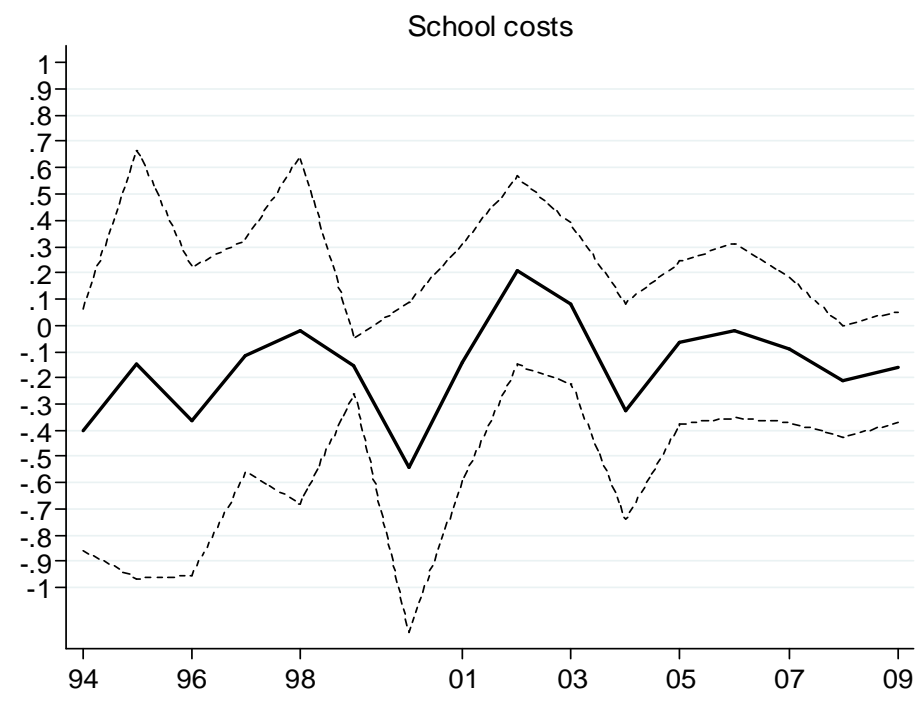

Note: Model 4' refers to model 4 including controls for initial characteristics as in column 4 of Table 8 .

\section{An analysis using TIMSS data}

Our positive estimates might appear surprising, given Sweden's relative decline in scores on international tests such as PISA and TIMSS since the mid-1990s. However, because we examine variation across municipalities it may well be the case that the municipalities where independent schooling have increased less have contributed most to this decline. To test this hypothesis, we perform an analysis using TIMSS data for Sweden. We have been able to link information on the municipality where each sample school is located, and thus also the information about independent school penetration, to the TIMSS data on students in the $8^{\text {th }}$ grade in 1995, 2003 and 2007. ${ }^{52}$ We first aggregate the data on each pupil's average score on the tests in Math and Science into two groups based on whether their school was located in a municipality above or below the median level of the share of independent school students in 2009. We determined this median in our main data set at the student level. This treatment makes us one group of 66 municipalities, among which the average change in the independent school share over time was 17.6 percentage points, and one group of 218 municipalities,

${ }^{52}$ We have not been able to obtain the corresponding information to identify municipalities in the PISA data. The TIMSS survey years are also more comparable to the years in our main analysis relative to the PISA survey years. 
among which the corresponding average change is 2.1 percentage points. Each group contains approximately one half of the student population in the $9^{\text {th }}$ grade. The aggregated TIMSS data contain 5,636 students in the first group and 5,784 students in the second group. ${ }^{53}$ Therefore, the proportions of the groups are very similar to our 100 percent sample, thereby confirming the representativeness of the TIMSS data.

The development over time in the TIMSS test score for the two groups is displayed in Figure 6. This figure shows that the average scores have declined over time for both types of municipalities and that this decline is somewhat smaller in municipalities where independent schooling has increased more. The difference between the two groups does not appear before 2003. This result is consistent with our finding that effects are observed many years after the reform (for fully treated cohorts).

\section{Figure 6: TIMSS Math/Science score by the share}

of independent school students in 2009

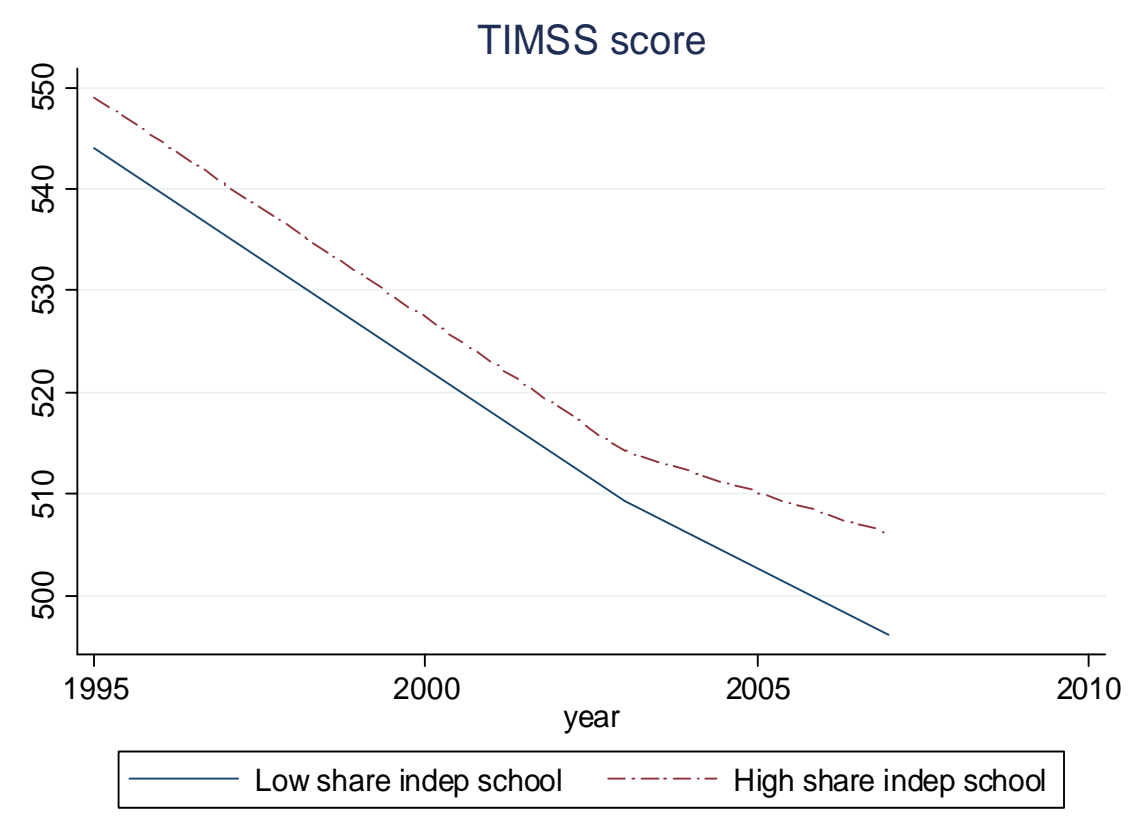

Next, we use the individual-level TIMSS data to estimate the following regression:

$$
Y_{i m c t}=\gamma_{c}+\alpha_{t}+\beta \bar{P}_{m c t}+\varepsilon_{i m c t},
$$

where Y represents individual i's test score on either Math or Science; $\gamma_{\mathrm{m}}$ represents unobservable county characteristics that are constant over time; and $\alpha_{\mathrm{t}}$ represents unobservable school-cohort characteristics that are constant across counties. We include only

\footnotetext{
${ }^{53}$ The TIMSS samples that we use contain data on 1,949 students in 1995; 4,256 students in 2003 and 5,215 students in 2007.
} 
the years 1995 and 2007 to mimic the main analysis as much as possible. ${ }^{54} \mathrm{We}$ believe it is reasonable to use within-county variation in this analysis in light of the small sample size. And, despite the small sample size, we have a balanced panel of all 24 Swedish counties. If we instead estimate this model with municipality fixed effects, we obtain similar point estimates, but these estimates are naturally very imprecise. ${ }^{55}$ The results are shown in Table 9 along with descriptive statistics for our two outcome variables. The estimates reveal that an increase in the share of independent school students with 10 percentage points is associated with an increase in TIMSS Math and Science test scores with approximately 12 points. This finding corresponds to approximately 17 percent of a standard deviation (the standard deviation is approximately 71 points 2007). If we transform our main estimates for the $9^{\text {th }}$ grade outcomes to standard deviation units (using the variation across all individuals), we find that a 10-percentage-point increase in the share of independent school students has resulted in a 4-5 percent of a standard deviation unit change. The larger estimates in the TIMSS analysis might to some extent be explained by the fact that we here perform weighted county-level estimation (and no time-varying controls) for a slightly different time period. Recall, however, that the main $9^{\text {th }}$ grade estimates do not change substantially when we perform weighted estimation or county-level estimation, exclude the covariates, or use 2007 as the last year instead of 2009 (or 1993 instead of 1992). Nevertheless, it is interesting that we find nontrivial positive estimates when we examine outcomes that are believed to be more accurate measures of student performance than test scores and grades in Sweden.

Table 9 OLS fixed-effects regressions relating the share of independent-school students in the municipality to TIMSS test scores for 1995 and 2007

\begin{tabular}{|c|c|c|c|c|c|}
\hline \multirow{3}{*}{ Outcome: } & \multirow{3}{*}{$(1)$} & \multicolumn{4}{|c|}{ Descriptive statistics } \\
\hline & & \multicolumn{2}{|c|}{1995} & \multicolumn{2}{|c|}{2007} \\
\hline & & Mean & St.dev & Mean & St.dev \\
\hline Math test score in TIMSS & $\begin{array}{c}114.49 \\
(35.35)^{* *}\end{array}$ & 540 & 74 & 491 & 67 \\
\hline $\mathrm{R} 2$ & 0.16 & & & & \\
\hline Science test score in TIMSS & $\begin{array}{c}125.43 \\
(35.79)^{* *}\end{array}$ & 453 & 78 & 511 & 74 \\
\hline $\mathrm{R} 2$ & 0.13 & & & & \\
\hline Number of individuals & 7164 & & & & \\
\hline County and year fixed effects & YES & & & & \\
\hline Number of counties & 24 & & & & \\
\hline Number of municipalities & 141 & & & & \\
\hline
\end{tabular}

Notes: The standard errors are clustered at the municipality level in all regressions. + significant at 10 percent; * significant at 5 percent; ** significant at 1 percent. All regressions are weighted by sampling weights using the "total student weight" in the TIMSS data.

\footnotetext{
${ }^{54}$ Another difference is that here we attach more weight to larger municipalities, as we estimate using individual-level data.

${ }^{55}$ For Math, we obtain 68.44 (113.75), and for Science, we obtain 104.67 (125.03).
} 


\section{Conclusion and discussion}

We have estimated general educational performance effects of choice and competition between public and independent schools in Sweden. For this purpose, we have used administrative data on compulsory school graduates in 1988-2009 and exploited betweenmunicipality differences in the growth in the share of independent-school students that developed as a consequence of the 1992 voucher reform. Our empirical strategy was to regress the change in educational performance outcomes on the increase in the share of independent-school students between Swedish municipalities.

We find that an increase in the share of independent-school students improves average educational performance both at the end of compulsory school and, in the long run, in terms of high school grades, university attendance and years of schooling. We further show that these effects are very robust with respect to a number of potential issues, such as grade inflation and pre-reform trends. We do also not find that our results are due to effects from other reforms such as the introduction of choice between public schools and the decentralization of school administration from the state to local governments. Interestingly, it appears that these positive effects are primarily due to spill-over or competition effects and not that independent-school students gain significantly more than public school students. We are also able to show that a higher share of independent-school students in the municipality has not generated increased school expenditures.

Notably, we have only been able to detect statistically significant positive effects on educational performance for later years, about a decade after the reform and onwards. However, this finding is not surprising, given that the first cohort of students who spent the entirety of their compulsory schooling in the new system graduated in 2001 and that it required time for independent schools to become more than a marginal phenomenon in Sweden. For university attendance and years of schooling we detect positive effects only for the very last year we are able to observe these outcomes (in 2003 and 2001, respectively). We therefore conclude that the overall evidence for long-term effects is weaker than for short- and medium-term effects, although we also note that the positive long-term effects turn up for about the same school cohorts that are the first to be observed with positive short-term effects.

The basic findings are that the impact of a 10-percentage-point increase in the share of independent-school students has resulted in close to a 2-percentile-rank higher educational achievement at the end of compulsory school and in high school, a 2-percentage-point higher probability of choosing an academic high-school track, a 2-percentage-point higher 
probability of attending university and almost an additional 4 weeks of schooling. We may compare our findings for short-term outcomes with evidence from previous Swedish studies (Ahlin, 2003; Björklund et al., 2005; Sandström and Bergström, 2005). These studies examine earlier and fewer post-reform years and yield mixed findings. If we transform our estimates to standard deviation (S.D.) units (using the variation across all individuals) we find that a 10percentage-point increase in the share of independent-school students has resulted in 0.040.05 S.D. higher average educational achievement at the end of compulsory school. Compared to the statistically significant findings in earlier studies, this result is less than half the size of the estimates for Math found in Ahlin (2003) and Swedish and English found in Björklund et al. (2005) and much lower than what was found for math in the IV estimations in Sandström and Bergström (2005). However, comparing our estimates using the actual school cohorts that they use in their analyses reveals that our estimates are even smaller and are often insignificant. ${ }^{56}$ The effects sizes we find are not enormous effects, but they are not trivial, either. For instance, we may compare these estimates to a recent study estimating the effect of smaller classes on student performance in Sweden (Fredriksson, Öckert and Oosterbeek, QJE, 2013). The magnitude of our effects (4\% of a S.D.) would be approximately similar in size to the positive effect of one fewer student in a class of 24 students. In their study, the authors find that this effect size is large enough for benefits to exceed costs if a policy of smaller classes were to be implemented.

Our positive estimates might appear surprising given Sweden's relative decline in scores on international tests such as PISA and TIMSS since the mid-1990s. However, by performing a separate analysis using student-level data from TIMSS for 1995, 2003 and 2007 disaggregated at the municipality level, we are able to reconcile these findings. We find that average tests scores have indeed deteriorated between 1995 and 2007 for Swedish students but have done so to a smaller extent in municipalities with a higher share of independent school students. Therefore, we do not find any support for the belief that an increase in the share of independent school students provides an explanation for Sweden's relative decline. If we compare our result with those of other countries, we find effects that are larger than what has been found for Canada (Card, Dooley and Payne, 2010) and Chile (Hsieh and Urquiola, 2006) but also that are more consistent with what has been found for the U.K. (Clark, 2009) and U.S. (Figlio and Hart, 2010). However, a comparison with other school systems is difficult, both because the alternative school types differ and because the conditions under which external effects work well might differ substantially. The conditions

\footnotetext{
${ }^{56}$ We discuss these earlier Swedish studies in greater detail in Böhlmark and Lindahl, 2007.
} 
for school choice that are likely to generate the most positive effects on overall school productivity are discussed in MacLeod and Urquiola (2009). Their framework is a reputation model of learning. The authors argue that in the Chilean system (where schools can select students based on ability), schools are more likely to compete by selecting the best students instead of by increasing productivity. In a system such as the Swedish system, where creamskimming is not allowed, the schools are more likely to compete by improving productivity. In fact, MacLeod and Urquiola (2009) state that if the reputation model holds for a school market, then "if schools cannot select on ability, the introduction of school choice will unambiguously raise school performance and student outcomes." The positive educational performance effects found in this paper and the absence of effects found in Hsieh and Urquiola (2006) support their story.

\section{References:}

Abdulkadiroglu, A., J. Angrist, S. Dynarski, T. Kane and P. Pathak, (2011), "Accountability and Flexibility in Public Schools: Evidence from Boston's Charters and Pilots," Quarterly Journal of Economics 126(2), pages 699-748

Ahlin, Å (2003), "Does school competition matter? Effects of a Large-scale School Choice Reform on Student Performance," Working Paper 2003:2, Department of Economics, Uppsala University.

Angrist, J., E. Bettinger, and M. Kremer (2006), "Long-Term Educational Consequences of Secondary School Vouchers: Evidence from Administrative Records in Columbia," American Economic Review 96 (3), 847-862.

Angrist, J. D., and J-S Pischke. Mostly Harmless Econometrics: An Empiricist's Companion. Princeton: Princeton University Press, 2008.

Bettinger, E. (2011) “Chapter 7 - Educational Vouchers in International Contexts,” pages 551 -572, in Handbook of the Economics of Education vol. 4, Edited by E. Hanushek, S. Machin and L. Woessmann.

Björklund, A, Clark, M, Edin, P-A, Fredriksson, P, and Krueger, A (2005), "The market comes to education in Sweden: An evaluation of Sweden's surprising school reforms," Russel Sage Foundation, New York.

Böhlmark, A and M. Lindahl (2007), "The Impact of School Choice on Pupil Achievement, Segregation and Costs: Swedish Evidence,” IZA Discussion Paper No. 2786.

Böhlmark, A and M. Lindahl (2008), "Does School Privatization Improve Educational Achievement? Evidence from Sweden's Voucher Reform.” IZA Discussion Paper No. 3691. 
Card, D., M. Dooley and A. Payne (2010) "School Competition and Efficiency with Publicly Funded Catholic Schools," American Economic Journal: Applied Economics, 2(4), pages $150-176$.

Chakrabarti, R. (2008). Can increasing private school participation and monetary loss in a Voucher program affect public school performance? Evidence from Milwaukee. Journal of Public Economics, 92(5-6), pages 1371-1393.

Clark, D. (2009), "Politics, Markets and Schools: Quasi-Experimental Estimates of the Impact of Autonomy and Competition from a Truly Revolutionary U.K. Reform," Journal of Political Economy, 117(4), pages 745-783.

Duflo, E. (2001) "Schooling and Labor Market Consequences of School Construction in Indonesia: Evidence from an Unusual Policy Experiment," American Economic Review 91(4): 795-813.

Figlio, D. and C. Hart (2010), "Competitive Effects of Means-Tested School Vouchers," NBER WP 16056.

Fredriksson, P., Öckert, B. and H. Oosterbeek (2013) "Long-Term Effects of Class Size". the Quarterly Journal of Economics, vol. 128(1), pp. 249-285.

Gibbons, S., S. Machin and O. Silva (2008), "Choice, Competition and Pupil Achievement," Journal of the European Economic Association, vol. 6(4), pp. 912-947.

Gill, B., M. Timpane, K. Ross, D. Brewer and K. Booker (2007). "Rhetoric versus reality : what we know and what we need to know about vouchers and charter schools," the RAND Corporation.

Grönqvist, E. and J. Vlachos (2008), "One size fits all? The effects of teacher cognitive and non-cognitive abilities on student achievement”, IFAU WP 2008:25

de Haan, M., E. Leuven and H. Oosterbeek (2011), "Scale Economies Can Offset the Benefits of Competition: Evidence from a School Consolidation Reform in a Universal Voucher System," IZA Discussion Papers 5528.

Hensvik, L. (2012), "Competition, Wages and Teacher Sorting: Lessons Learned from a Voucher Reform," Economic Journal, forthcoming.

Howell, W. G. and P.E. Peterson (2006). "The Education Gap: Vouchers and Urban Schools," Brookings Institution Press, Washington DC.

Hoxby, C. (2000), "Does competition among public schools benefit students and taxpayers," American Economic Review 90 (5), 1209-1238.

Hoxby, C. (2003). School choice and school competition: Evidence from the United States. Swedish Economic Policy Review) 10(2), pages: 9-65 
Hoxby, C. and S. Murarka (2009), "Charter Schools in New York City: Who Enrolls and How They Affect Their Students' Achievement,” NBER WP 14852.

Hsieh, C-T and M. Urquiola (2006), "The effects of generalized school choice on achievement and stratification: Evidence from Chile's voucher program," Journal of Public Economics 90, 1477-1503.

Lavy, V. (2010). "Effects of Free Choice Among Public Schools," Review of Economic Studies 77, pages 1164-1191.

MacLeod, B and M. Urquiola (2009), "Anti-Lemons: School Reputation and Educational Quality," NBER Working Papers 15112.

McEwan, P. J. (2000), “The Potential Impact of Large-Scale Voucher Programs.” Review of Educational Research 70:103-149.

Sahlgren, G.H. (2010), "Schooling for Money: Swedish Education Reform and the Role of the Profit Motive," IEA Discussion Paper No. 33.

Sandström, M and F. Bergström (2005), "School Vouchers in Practice: Competition Will Not Hurt You,” Journal of Public Economics 89, 351-380.

SOU (2008). ”Bidrag på lika villkor,” SOU 2008:8, Fritzes, Stockholm.

Swedish National Agency for Education (2001), "Fristående grundskolor - 2001," rapport Dnr 2001:3925, Skolverket.

Swedish National Agency for Education (2003), "Valfrihet och dess effekter inom skolområdet," rapport, Skolverket.

Swedish National Agency for Education (2004), “TIMSS 2003,” report 255.

Swedish National Agency for Education (2005), "Skolor som alla andra? Med fristående skolor i systemet 1991-2004," Skolverket, rapport 271.

Swedish National Agency for Education (2006), "Provbetyg-Slutbetyg-Likvärdig bedömning?," rapport 300 .

Vlachos, J. (2010) "Betygets värde. En analys av hur konkurrens påverkar betygssättningen vid svenska skolor", Konkurrensverket rapport 2010:6 
Table A1: Estimates from first stage regressions for the IV estimates in columns 6-8 in Table 4. Endogenous variable is the share of independent-school students

\begin{tabular}{|c|c|c|c|c|c|c|c|c|c|c|c|c|}
\hline & \multicolumn{3}{|c|}{ Grade and tests scores } & \multicolumn{3}{|c|}{ Academic HS track and HS grades } & \multicolumn{3}{|c|}{ University attendance } & \multicolumn{3}{|c|}{ Years of schooling } \\
\hline The share of independent schools & $\begin{array}{c}0.27 \\
(0.02)^{* * * *}\end{array}$ & & & $\begin{array}{c}0.20 \\
(0.02)^{* * *}\end{array}$ & & & $\begin{array}{c}0.16 \\
(0.02)^{* * *}\end{array}$ & & & $\begin{array}{c}0.12 \\
(0.01)^{* * * *}\end{array}$ & & \\
\hline $\begin{array}{l}\text { The density of students minus } \\
\text { density of schools in } 1992\end{array}$ & & $\begin{array}{c}0.065 \\
(0.022) * * *\end{array}$ & $\begin{array}{c}0.064 \\
(0.022)^{* * *}\end{array}$ & & $\begin{array}{c}0.080 \\
(0.016) * * *\end{array}$ & $\begin{array}{c}0.079 \\
(0.016)^{* * *}\end{array}$ & & $\begin{array}{c}0.076 \\
(0.013)^{* * *}\end{array}$ & $\begin{array}{c}0.076 \\
(0.013)^{* * *}\end{array}$ & & $\begin{array}{c}0.027 \\
(0.009)^{* * *}\end{array}$ & $\begin{array}{c}0.023 \\
(0.009)^{* * *}\end{array}$ \\
\hline $\begin{array}{l}\text { Existing private school in the } \\
\text { municipality in } 1992\end{array}$ & & & $\begin{array}{c}0.029 \\
(0.018)\end{array}$ & & & $\begin{array}{c}0.008 \\
(0.014)\end{array}$ & & & $\begin{array}{c}0.015 \\
(0.011)\end{array}$ & & & $\begin{array}{c}0.028 \\
(0.007)^{* * * *}\end{array}$ \\
\hline $\begin{array}{l}\text { More than one public school in the } \\
\text { municipality in } 1992\end{array}$ & & & $\begin{array}{c}0.016 \\
(0.009)^{*}\end{array}$ & & & $\begin{array}{c}0.018 \\
(0.007)^{* * *}\end{array}$ & & & $\begin{array}{c}0.014 \\
(0.005)^{* * *}\end{array}$ & & & $\begin{array}{c}0.007 \\
(0.003)^{*}\end{array}$ \\
\hline \multicolumn{13}{|l|}{$\mathbf{R 2}$} \\
\hline F-statistic & 145.99 & 8.77 & 4.94 & 130.35 & 24.03 & 10.89 & 50.15 & 33.46 & 14.60 & 86.40 & 9.13 & 10.77 \\
\hline \multicolumn{13}{|l|}{ Controls } \\
\hline Changes in municipal controls ${ }^{\mathrm{a}}$ & Yes & Yes & Yes & Yes & Yes & Yes & Yes & Yes & Yes & Yes & Yes & Yes \\
\hline Number of municipalities & 284 & 284 & 284 & 284 & 284 & 284 & 284 & 284 & 284 & 284 & 284 & 284 \\
\hline
\end{tabular}

